\title{
In Vitro Screening for the Tumoricidal Properties of International Medicinal Herbs
}

\author{
Elizabeth A. Mazzio and Karam F. A. Soliman ${ }^{*}$ \\ College of Pharmacy and Pharmaceutical Sciences, Florida A \& M University, Tallahassee, \\ Florida 32307, USA
}

\begin{abstract}
There is growing use of anticancer complementary and alternative medicines (CAMs) worldwide. The purpose of the current study is to assess a sizeable variety of natural and plant sources of diverse origin, to ascertain prospective research directives for cancer treatment and potential new chemotherapy drug sources. In this study, 374 natural extracts $(10 \mu \mathrm{g} / \mathrm{mL}-5 \mathrm{mg} / \mathrm{mL})$ were evaluated for dose-dependent tumoricidal effects using immortal neuroblastoma of spontaneous malignant origin. The findings indicate no pattern of tumoricidal effects by diverse plants with similar families/genus under the classes Pinopsida, Equisetopsida, Lycopodiosida, Filicosida, Liliopsida Monocotyledons or Magnoliopsida Dicotyledons. The results indicate that many of the most commonly used CAMs exhibited relatively weak tumoricidal effects including cats claw, astragalus, ginseng, echinacea, mistletoe, milk thistle, slippery elm, cayenne, chamomile, don quai, meadowsweet, motherwort and shepherd's purse. The data demonstrate that the most potent plant extracts were randomly dispersed within the plantae kingdom $\left(\mathrm{LC}_{50}=31-490 \mu \mathrm{g} / \mathrm{mL}\right)$ in order of the lowest $\mathrm{LC}_{50}$ Dioscorea villosa (Dioscoreaceae) $>$ Sanguinaria canadensis (Papaveraceae) $>$ Dipsacus asper (Dipsacaceae) $>$ Populus balsamifera $($ Salicaceae) $>$ Boswellia carteri (Burseraceae) $>$ Cyamopsis psoralioides (Fabaceae) $>$ Rhamnus cathartica (Rhamnaceae) $>$ Larrea tridentate (Zygophyllaceae) > Dichroa febrifuga (Hydrangeaceae) > Batschia canescens $($ Boraginaceae) $>$ Kochia scoparia $($ Chenopodiaceae) $>$ Solanum xanthocarpum $($ Solanaceae) $>$ Opoponax chironium (Umbelliferae) $>$ Caulophyllum thalictroides (Berberidaceae) $>$ Dryopteris crassirhizoma (Dryopteridaceae) > Garcinia cambogia (Clusiaceae) > Vitex agnus-castus (Verbenaceae) > Calamus draco (Arecaceae). These findings show tumoricidal effect by extracts of wild yam root, bloodroot, teasel root, bakuchi seed, dichroa root, kanta kari, garcinia fruit, mace, dragons blood and the biblically referenced herbs: balm of gilead bud, frankincense and myrrh gum.
\end{abstract}

\section{Keywords}

herbs; screening; cancer; wild yam; frankincense; teasel; myrrh

\section{INTRODUCTION}

The term complementary and alternative medicine (CAM) is customary in describing various alternative approaches to augment the health of mind, body and spirit in order to enhance traditional medical approach to disease treatment. There is an increase of worldwide CAM use due to many influences that include a rise in the cost of health care,

Copyright $\odot 2008$ John Wiley \& Sons, Ltd.

*Correspondence to: Dr Karam F. A. Soliman, College of Pharmacy and Pharmaceutical Sciences, Florida A \& M University, Tallahassee, FL 32307, USA. E-mail: karam.soliman@ famu.edu. 
information technology and a greater global conscience toward the importance of holistic medicine. In countries such as Japan, Korea, India and China, botanical therapeutics are often administered by a practicing medical professional and are classified as traditional 'medicines'. In the USA, many of these same plants are termed 'supplements' which are sold with applicable legal restriction preventing sale and dispensation without a claim to 'treat' a disease.

There is a distinction between CAM approaches for cancer prevention versus disease treatment. Chemoprevention involves implementing dietary changes that allow for higher intake of nutrients that augment biochemical defense mechanisms to antagonize initiation, promotion and progression of carcinogenesis. Preventative dietary patterns often exclude foods known to precipitate cancer such as a high-fat diet (Blackburn and Wang, 2007) or allow for greater intake of protective nutrients such as B vitamins which serve to augment immune function, contribute to proper cell division and reduce incidence of dysplasia (Hernandez et al., 2003). Other preventative dietary measures include the incorporation of xenobiotic nutrients (Conney, 2003), antioxidants (Blot, 1997; Rosenberg et al., 2002) and dietary oils that mediate effects on prostaglandins (Calviello et al., 2007). Dietary chemoprevention is a means to establish greater physiological resistance against insults to cellular DNA otherwise caused by carcinogens, environmental pollutants, nitrosamines, polycyclic aromatic hydrocarbons in foods, viruses, radiation and reactive oxygen species.

After malignancy has been diagnosed and established, CAM choices would serve to augment chemotherapy, contribute to tumor suppression, prevent metastasis and establish remission. It is estimated that up to $91 \%$ of cancer patients worldwide are now seeking some form of CAM to augment traditional chemotherapy, with the largest fraction comprising self-administered herbs, herbal teas, vitamins and minerals with the highest percentages observed in breast, colon, lung, head and neck cancer patients (Yates et al., 2005; Molassiotis et al., 2006; Scott et al., 2005). Although many of these CAM practices are conducted without apprising medical professionals, prevalent choices are known to include the use of nettle, mistletoe, ginseng, cayenne, chamomile, don quai, feverfew, ginko, green tea, kava, milk thistle, licorice, meadowsweet, motherwort, senna leaf, shepherds purse, ginger and turmeric (Advance Data, CDC, 2004; Kumar et al., 2005; Melnick, 2006; Gerson-Cwilich et al., 2006; Dy et al., 2004; Hu et al., 2005).

While there are many sporadic studies investigating individual plants for anticancer effects within the literature, there are few studies which examine these plants side by side for relative therapeutic efficacy under identical experimental conditions. In this study we evaluate many popular CAMs amidst a total of 374 naturally derived, herbs, seeds, roots, plankton and fungi extracts to establish relative tumoricidal potency in vitro using a murine malignant neuroblastoma cell line. Also incorporated, is a discussion as to safety issues that circumscribe the use of the most potent extracts demonstrated in this study, including information from prior research, advisories by the American botanical counsel and the German Herbal Regulatory Commission E monographs. The commission E monographs are an established report put out by the German government to give the public information regarding approved uses for herbs, including advisories, potential side effects, acceptable dosage, drug interactions and therapeutic efficacy. This study shows that many of the most popular anticancer CAMs showed relatively weak anticancer properties when compared with other international plants, some of which have not yet been reported in the scientific or historical literature pertaining to the field of cancer. 


\section{METHODS AND MATERIALS}

The N-2A cells were purchased from American Type Culture Collection (Manassas, VA). Dulbecco's Modified Eagle Medium (DMEM), s-glutamine, fetal bovine serum - heat inactivated (FBS), phosphate buffered saline (PBS), Hank's balanced salt solution (HBSS) and penicillin/streptomycin were purchased from Fischer Scientific, Mediatech, (Pittsburgh, PA, USA). Herbs were purchased from Frontier Natural Brands, (Norway, Iowa, USA), Mountain Rose Herbs (Eugene, OR, USA) and Kalyx Natural Marketplace (Camden, NY, USA). All other chemicals and research supplies were purchased from Sigma Chemical (St Louis, MO, USA).

\section{Extraction and sample preparation}

All crude plants were weighed $(0.25 \mathrm{~g})$, pulverized, macerated/homogenized and extracted in $1000 \mu \mathrm{L}$ of absolute ethanol for 7 days at $4{ }^{\circ} \mathrm{C}$ (Chakraborty et al., 2004). A stock solution for each extract was subsequently prepared by dilution to $10 \mathrm{~mL}$ with HBSS $+5 \mathrm{~mm}$ ( $N$-[2-hydroxyethylpiperazine- $N^{\prime}$-[2-ethanesulfonic acid]) (HEPES), pre-adjusted to a pH of 7.4 with $0.1 \times \mathrm{NAOH}$. Six serial dilutions of each experimental extract were prepared from the stock solution in order to span a 1000-fold concentration gradient with the highest final plating concentration set at $5 \mathrm{mg} / \mathrm{mL}(\mathrm{w} / \mathrm{v})$.

\section{Cell culture}

Neuro-2a cells were used in this study to screen for tumoricidal effects, as the cell line was established from a malignant spontaneous tumor and previously deemed an appropriate model to evaluate potential chemotherapy drugs for the treatment of cancer (Finklestein $e t$ al., 1975; Klebe and Ruddle, 1969; Mazzio et al., 2003). Briefly, N-2A cells were cultured in DMEM + phenol red supplemented with 10\% FBS, 4 m $\mathrm{m}$-glutamine, $20 \mu_{\mathrm{M}}$ sodium pyruvate and penicillin/streptomycin (100 Units/ $0.1 \mathrm{mg}, \mathrm{mL})$. The cultures were maintained at $37{ }^{\circ} \mathrm{C}$ in $5 \% \mathrm{CO}_{2} /$ atmosphere and co-cultured every 2-3 days. Experimental plating media consisted of DMEM (-phenol red) supplemented with 1.8\% FBS, penicillin/streptomycin $(100$ Units $/ 0.1 \mathrm{mg} / \mathrm{mL}), 20 \mu_{\mathrm{M}}$ sodium pyruvate and $4 \mathrm{~m} \mathrm{~m}$-glutamine. The cells were plated in 96-well plates at a density of approximately $0.5 \times 10^{6}$ cells $/ \mathrm{mL}$. A first tier screening was conducted at final plating concentrations of $0.5-5.0 \mathrm{mg} / \mathrm{mL}$ to identify extracts that exhibit an $\mathrm{IC}_{50}$ less than $5.0 \mathrm{mg} / \mathrm{mL}$. A second and third tier screening was conducted using the same procedure at lower concentrations in order to establish an accurate $\mathrm{LC}_{50}$ for those demonstrating toxicity at less than $0.5 \mathrm{mg} / \mathrm{mL}$.

\section{Evaluation of cellular toxicity}

Cell viability was assessed by resazurin-almar blue indicator dye as described previously (Mazzio et al., 2003). Experimental blanks and extract controls were run simultaneously with samples, in order to detect any interferences or reactivity with the dye or cell viability. Briefly, almar blue was dissolved in sterile PBS $(0.5 \mathrm{mg} / \mathrm{mL})$ and the cell viability was assessed by quantifying the reduction of the dye to its corresponding fluorescent intermediate - resorufin. The use of fluorescence for cell viability eliminates significant interferences introduced by experimental compounds themselves, otherwise presented during UV detection using spectrophotometric dyes. The fluorescence intensity was analysed using a microplate fluorometer - Model 7620 version 5.02 (Cambridge Technologies Inc, Watertown, Mass) with settings held at [550/580], [excitation/emission].

\section{Evaluation of cell death}

Propidium iodide (PI) was used to corroborate viability studies with the most potent extracts. PI is nucleic acid stain which represents cell death as described previously (Mazzio 
et al., 2003). Samples were analysed photographically using an Olympus IX-70 inverted microscope and images were captured using a MD35 Electronic Eyepiece (Zhejiang Jincheng Science and Technology Co., Ltd, China) with analysis performed using Cimaging systems confocal PCI-Simple software (Compix Inc. Cranberry Township, PA, USA).

\section{Data analysis}

Statistical analysis was performed using both Origin Lab Scientific Evaluation Software (version 7.5 SR6) (Original Lab Corp., Northampton, MA, USA) and Graphpad Prism (version 3.0), (Graphpad Software Inc. San Diego, CA, USA). The lethal concentrations $\left(\mathrm{LC}_{50}\right)$ were established from dose-dependent data with Origin Lab 7.5 SR6 and significance of difference between the groups was assessed using a one-way ANOVA, followed by a Tukey post hoc means comparison test using Graphpad Prism Ver 3.0 software.

\section{RESULTS}

The data in Table 1 are categorized under five classifications based on the established lethal concentration. These include Category 1 , strongest $\mathrm{LC}_{50}=0.19-0.528 \mathrm{mg} / \mathrm{mL}$; Category 2, moderate to strong $\mathrm{LC}_{50}=0.528-1.197 \mathrm{mg} / \mathrm{mL}$; Category 3, moderate $\mathrm{LC}_{50}=1.259-2.515$ $\mathrm{mg} / \mathrm{mL}$; Category 4, weak to moderate $\mathrm{LC}_{50}=2.528-4.939 \mathrm{mg} / \mathrm{mL}$ and Category 5, weak $\mathrm{LC}_{50}>5.0 \mathrm{mg} / \mathrm{mL}$. These classifications denote the $\mathrm{LC}_{50}$ calculated from dose-dependent cell death. Cell viability and cell death were determined separately (Figs 1-12) for the most potent herbs otherwise classified in Table 1 . The data indicate the greatest promise for the extracts of wild yam root, teasel root, balm of gilead bud and frankincense, amongst others discussed. An asterisk indicates herbs that can be used at a low to moderate concentration with little or no reported side effects. Interestingly, the data from this study showed no patterns of tumoricidal rank amongst various plants from the same division, order, class and family. The findings from this study suggest that botanical taxonomy does not appear to be a predictor in establishing tumoricidal effects, as much as the unique property and constituents of each plant.

\section{DISCUSSION}

The current study investigates a diverse range of plants for tumoricidal properties using an established malignant tumor cell line. While, in vitro screenings are a robust tool providing indicative measure of potential chemotherapy drugs, limitations involve further in depth research requirements to examine gastrointestinal absorption rates, bio-availability, systemic circulation, liver metabolism, catabolism of active constituents, urinary and fecal excretion, distribution to target organs, cellular transport and side effects all which contribute to efficacy in vivo (Lin, 1998). However, the data as presented in this study reveal promising tumoricidal effects $\left(\mathrm{LD}_{50}<0.1 \mathrm{mg} / \mathrm{mL}\right)$ for extracts of wild yam root, blood root, balm of gilead, teasel root and frankincense. Further, many of the most potent herbal extracts as reported in study, have not yet been researched in the scientific literature pertaining to the field of cancer.

\section{Most potent plant extracts}

Wild yam root (Dioscorea villosa) was found to be the most potent herbal extract with an $\mathrm{LC}_{50}=0.019 \mathrm{mg} / \mathrm{mL}$. Although there is little or no research regarding the use of this herb in experimental investigation of malignancy, wild yam root is known to contain indigenous plant phytosterol estrogens such as diosgenin, which espouse therapeutic effects on female hormonal regulation and alleviate the symptoms of menopause. However, diosgenin is 
known to induce antiproliferative pro-apoptotic effects in a diverse range of tumor cells by arresting G2/M, down-regulating NF-kappa B, Akt, cyclin D, c-myc and initiating PARP cleavage/DNA fragmentation (Shishodia and Aggarwal, 2006; Leger et al., 2006; Liagre et al., 2005). This herb root is also known to contain sapogenins, phytosterols, beta-sitosterol and campesterol, which may contribute in part to the tumoricidal properties (Dr Dukes Chemical Database). Overall, the American Herbal Products Association - Botanical Safety Handbook (AHPA-BSH) has defined wild yam root as a Class 1 herb (safest herb category), further defined as 'herbs which can be safely consumed when used appropriately' (McGuffin, 1997). However, caution should be advised since it has been reported that administration in animals while safe at $0.5 \mathrm{mg} / \mathrm{kg}$, when administered at $2 \mathrm{~g} / \mathrm{kg}$ can induce hypoactivity, piloerection, dyspnea and death (No authors, 2004). In this study, bloodroot extract (Sanguinaria canadensis) was the second most potent $\left(\mathrm{LC}_{50}=0.04 \mathrm{mg} / \mathrm{mL}\right.$ ). However, controversy surrounds its use as a primary ingredient in the marketed antiskin cancer salve sold under the name 'black salve' or 'can- $\mathrm{x}$ '. While there are few or no established research studies which investigate the anticancer effects of bloodroot, the inherent constituents of the plant such as sanguinarine (a toxic benzophenanthridine alkaloid) are known to incur major side effects such as tissue corrosion, scarring and possible worsening of basal cell carcinoma to an aggressive malignant form (McDaniel and Goldman, 2002). On the other hand, the therapeutic effects of sanguinarine and sanguinaria have been shown to combat gingivitis and plaque and are deemed relatively safe for the intended purpose, also having been approved by the FDA for commercial products manufactured by the Colgate-Palmolive Company (Frankos et al., 1990). While administration of sanguinarine is fairly safe at very low concentrations, at high concentrations it is deadly given its ability to inhibit $\mathrm{Na}^{+} \mathrm{K}^{+}$ATPase in cardiac tissue in a similar fashion to ouabain (Seifen et al., 1979). Further, bloodroot also contains the toxic alkaloid berberine, which can lead to adverse side effects on cardiac function, respiration, blood pressure and the use of this herb is contraindicated during pregnancy (McGuffin, 1997). Bloodroot is also known to contain a range of benzophenanthridine alkaloids, isoquinoline alkaloids, chelerythrine, sanguidimerine, protopine and trace elements which vary with the seasonal harvest and plant distinction (Graf et al., 2007). The dangers associated with this herb may in fact outweigh its therapeutic benefits.

Unlike wild yam and bloodroot, teasel root (Dipsacus asper) $\left(\mathrm{LC}_{50}=0.042 \mathrm{mg} / \mathrm{mL}\right)$ is often used by consumers at appreciably high dose without reported side effects. Teasel root is generally known to treat lime disease, fibromyalgia and serve as a general cleanser for the liver, kidney, digestive and circulatory systems, representing overall positive effects on the central organs. While there is no experimental research investigating teasel root's anticancer effects, a recent study has suggested that its antioxidant properties may contribute to a potential treatment for Alzheimer's disease (Zhang et al., 2003). Ethanol extracts of Dipsacus asper are known to contain phenolic acids including caffeic acid, 2,6dihydroxycinnamic acid, vanillic acid, 2'-O-caffeoyl-o-glucopyranoside ester, and caffeoylquinic acid, iridoid glucosides, triterpenoids oleanic acid and akebiasaponin D (Tian et al., 2007). Teasel root is commonly sold with a suggested product dose of 6-21 g/day and categorized as an AHPA-BSH 'Class 1 herb'; therefore this herb holds considerable promise as a holistic anticancer CAM (McGuffin, 1997). There is also a complete nonappearance in the scientific literature regarding investigative applications for balm of gilead bud (Populus balsamifera) $\left(\mathrm{LC}_{50}=0.078 \mathrm{mg} / \mathrm{mL}\right)$. Historically, this herb was used by Native Americans for the treatment of general maladies including urinary tract infection, wounds, colds, arthritis, pains and coughs and as an insect repellent. Balm of gilead bud has also been approved as 'safe' by the German Commission E for topical applications only; including skin disease, hemorrhoids, frostbite and sunburn (Bundesinstitut fur Arzneimittel und Medizinprodukte, 1998). However, alcohol extracts of balm of gilead bud are sold by a number of manufacturers with instructions for internal use up to $2 \mathrm{~mL} / \mathrm{day}$, with no known 
reported side effects. While this is a AHPABSH 'Class 1 herb' indicating safety, the German Commission E cautions use by individuals who demonstrate allergic responses to propolis or aspirin (salicylic acid), this showing a greater percentage in those who suffer from hives, asthma and sinus infections (McGuffin, 1997; Bundesinstitut fur Arzneimittel und Medizinprodukte, 1998). In addition, extracts derived from this species of plant are known to contain beta-eudesmol, alpha-eudesmol, gamma-selinene, cadinene, alpha-elemene, hemiterpenes, sesquiterpenes, alcohols, carbonyl compounds, hydroxyacids, aliphatic acids, phenolcarboxylic acids and substituted cinnamic acids (Jerkovi and Mastelic, 2003; Isidorov and Vinogorova, 2003).

Interestingly, the three biblical herbs: balm of gilead bud, frankincense and myrrh show significant tumoricidal effects as demonstrated in this study. The reported use of frankincense (Boswellia carteri) dates back to 3000 B.C. primarily used as an incense until the year $200 \mathrm{AD}$, where its use expanded to medicinal purposes for the treatment of gout, ulcers, oral health and also for the production of manufactured plasters (Hillson, 1988). The potential for frankincense as an anticancer agent in this study $\left(\mathrm{LC}_{50}=0.081 \mathrm{mg} / \mathrm{mL}\right)$ corroborates previous reports, where the extract is able to inhibit topoisomerase II in mouse leukemia L1210 cells in a similar fashion to etoposide and aclarubicin (Wang et al., 1991). This species of plant is known to contain plant chemical constituents including acetyl-alphaboswellic acid, acetyl-beta-boswellic acid, lup-20(29)-ene-3 alpha-acetoxy-24-oic acid, alpha-boswellic acid, beta-boswellic acid and acetyl-11-keto-betaboswellic acid (Zhou and Cui, 2002). The boswellic acid pentacyclic triterpenes derived from the gum resin are more potent than campthothecin, amsacrine or etoposide in inhibiting human topoisomerases I and II alpha, through high-affinity binding sites (Syrovets et al., 2000). Boswellic acids also exert direct antiproliferative/pro-apoptotic effects through activation of caspase-3/8/9 and PARP cleavage in HT-29 cells (Liu et al., 2002), human leukemia cells HL-60, K 562, U937, MOLT-4, THP-1 and brain tumor cells LN-18, LN-229 (Hostanska et al., 2002). Due to the historical use of frankincense, and the AHPA-BSH classification of this herb as a Class 1 herb, this could also be potential anticancer CAM (McGuffin, 1997). Boswellia serrata extract is available and sold in capsule form with a suggested intake of approximately $400 \mathrm{mg}$ ( $3 \times$ daily), with no known side effects having been reported.

There is also extended historical information regarding the use of myrrh (Commiphora molmol) dating back centuries for treatment of infection, pain, swelling, leprosy and halitosis. The present study shows tumoricidal effects by myrrh gum $\left(\mathrm{LC}_{50}=158 \mu \mathrm{g} / \mathrm{mL}\right)$ corroborating previous reports that it induces apoptosis in lung, pancreas, breast and prostate cancer cell lines with an $\mathrm{LC}_{50}$ less than $500 \mu \mathrm{g} / \mathrm{mL}$ in vitro (Shoemaker et al., 2005). In animal studies, its administration induces tumoricidal effects equal to cyclophosphamide in Ehrlich-solid-tumorbearing mice (Qureshi et al., 1993). In terms of safety, it should be noted that lethal effects have been observed at high concentration, where oral intake of $1-5 \mathrm{~g} / \mathrm{kg}$ day induces jaundice, ataxia, dyspnea, soft feces, hepatonephropathy, leucopenia macrocytic anemia hemorrhagic myositis and death in mammals (Omer et al., 1999). In humans, oral intake of myrrh was tolerated for 3 days $(10 \mathrm{mg} / \mathrm{kg})$ in experimental treatment of schistosomiasis without adverse affects on liver/kidney function (Sheir et al., 2001). While the Commission E has approved myrrh for topical treatment of neck and mouth inflammations, this is nonetheless a AHPA-BSH Class 2 herb where excessive use can lead to irritation of the kidneys and it is counter-indicated during pregnancy (McGuffin, 1997; Bundesinstitut fur Arzneimittel und Medizinprodukte, 1998). Extracts of myrrh contain a diverse range of constituents including selinene, furanodiene, $\beta$-selinene, lindestrene, furanoeudesma-1,3-diene, $\beta$-elemene, $\gamma$-elemene, $\delta$-elemene, elemol, isofuranogermacrene, curzerenone, $\alpha$-cubebene and $\beta$-bourbonene (Hanus et al., 2005). 


\section{Potent plant extracts with little to no reported side effects}

Briefly, the data in this study show promising results for several other plants which are not associated with known side effects when used in humans some of which include: Bakuchi seed (Cyamopsis psoralioides) $\left(\mathrm{LC}_{50}=0.102 \mathrm{mg} / \mathrm{mL}\right)$ typically used for the treatment of leprosy, jaundice, infections, tumors, baldness, snake and scorpion bites; Dichroa root (Dichroa febrifuga) $\left(\mathrm{LC}_{50}=0.107 \mathrm{mg} / \mathrm{mL}\right)$, an antimalarial agent and Kanta kari $\left(\mathrm{LC}_{50}=\right.$ $0.157 \mathrm{mg} / \mathrm{mL}$ ) commonly used for treatment of asthma and respiratory infections of which its clinical and experimental use in animals is effective for intended purpose without side effects (Govindan et al., 2004). Another popular plant extract showing a low $\mathrm{LC}_{50}=0.235$ $\mathrm{mg} / \mathrm{mL}$ was Garcinia fruit (Garcinia cambogia), effects of which has been reported in the scientific literature. Garcinia fruit contains prenylated xanthones in part responsible for inhibiting pre-neoplastic lesions in mammary/colon cancer (Nabandith et al., 2004) and induces apoptosis in mouth, leukemia, breast, gastric and lung cancer cell lines in vitro (Suksamrarn et al., 2006; Matsumoto et al., 2003). Indigenous xanthones such as gambogic acid can down-regulate c-MYC mRNA expression/telomerase reverse transcriptase gene, disrupting cell proliferation and the immortalization of human cancer cells (Liu et al., 2005; Zhang et al., 2004) also blocking tumor growth of SMMC-7721 transplanted carcinoma in vivo (Guo et al., 2004).

Another plant constituent is garcinol (a polyisoprenylated benzophenone within the plant) known to impair cell proliferation, cancer cell migration, cell adhesion and cancer cell viability, via inhibiting MAPK/ERK, PI3K/Akt, the phosphorylation of membrane focal adhesion kinase and augmenting BAX, caspase $2 / 3$ activation, release of cytochrome $C$ and PARP-1 cleavage in a diverse range human cancer cell lines (Liao et al., 2005; Pan et al., 2001). The recommended dosage for oral intake of Garcinia cambogia is estimated at up to $6 \mathrm{~g} /$ day. There is significant potential for this fruit, since it is well tolerated at significant doses also sold as a popular fruit juice under the tradename Xango®. Vitex (Agnus castus) $\left(\mathrm{LC}_{50}=0.302 \mathrm{mg} / \mathrm{mL}\right)$, also known as chasteberry is used traditionally for regulating homeostasis of women reproductive physiology and ameliorating the symptoms of PMS, amenorrhea, infertility and meno-pause. Like wild yam, the mechanism of action for vitex may involve its phytoestrogenic fraction where the extract $(<100 \mu \mathrm{g} / \mathrm{mL})$ is capable of inducing cell death in a diverse range of tumor cell lines including ovarian, cervical, breast, gastric, colon and lung via induction of pro-apoptotic caspase 3, $89 \mathrm{HO}$ oxidase, a reduction in BCL-2 Bcl-XL and Bid protein, the increase in Bad gene expression and induction of DNA fragmentation (Ohyama et al., 2003, 2005; Liu et al., 2002). Given that low doses can yield significant tumoricidal properties, with relatively mild or reversible side effects with no reported drug interactions, this herb shows some promise.

The Commission $\mathrm{E}$ has approved its use for irregularities of the menstrual cycle, premenstrual complaints and mastodynia. Unless otherwise prescribed, 30-40 mg (0.03-0.04 g) per day of crushed fruit for aqueous-alcoholic extracts in dry or fluid form is acceptable'. However, this is a AHPA-BSH Class $2 b$ herb also known as an emmenagogue herb, where it can counteract with the efficacy of birth control pills, and should not be used during pregnancy due to its has effects on uterine contraction (McGuffin, 1997; Bundesinstitut fur Arzneimittel und Medizinprodukte, 1998). Rosemary leaf (Rosmarinus officinalis) $\left(\mathrm{LC}_{50}=\right.$ $0.299 \mathrm{mg} / \mathrm{mL}$ ) also has a long history where its use involves application for cooking and medicinally to treat muscle pain, indigestion, arteriosclerosis, alopecia and bacterial infections. Extract of rosemary increases sensitivity and prevents efflux of chemotherapeutic agents in drug resistant MCF-7 human breast cancer cells (Plouzek et al., 1999) and inhibits 7,12-dimethylbenz[a]anthracene induced mammary tumorigenesis in female rats (Singletary et al., 1996). Inherent active constituents such as carnosol (a phenolic compound extracted from rosemary) are found to be lethal against acute lymphoblastic leukemia cells (Dorrie $e t$ al., 2001) and colon cancer in vivo (Moran et al., 2005). Due to the historical use of 
rosemary, and the suggested use of 4- $6 \mathrm{~g} /$ day, this herb could be proving significant as an anticancer CAM.

The Commission E `approved the internal use of rosemary leaf for dyspeptic complaints and external use as supportive therapy for rheumatic diseases and circulatory problems. No reported drug interactions, side effects and recommended use is 4-6 $\mathrm{g}$ of cut leaf for infusions, powder, dry extracts and other galenical preparations for internal and external use' (Bundesinstitut fur Arzneimittel und Medizinprodukte, 1998). AHPA-BSH has classified rosemary as a Class 2 b/emmenagogue herb where it can stimulate uterine contraction and induce miscarriage, establishing counter-indication of use during pregnancy. In contrast to ethanol extracts, the oil of rosemary can have dangerous side effects including nausea, vomiting, seizure and pulmonary edema. Ginger (Zingiber officinale) $\left(\mathrm{LC}_{50}=0.477 \mathrm{mg} /\right.$ $\mathrm{mL}$ ) has been used for centuries as a cooking spice and medicinally demonstrates a diverse range of applications having biological properties such as the ability to modulate platelet aggregation, serve as an analgesic, antiinflammatory, hypoglycemic, antimicrobial, antiparasitic activity and antioxidant, also commonly used for nausea. Ginger and its constituents induce apoptosis in human cancer cell lines (Wei et al., 2005) and display anticancer properties against spontaneous tumors in animal models (Nagasawa et al., 2002). In humans, the administration of ginger up to $6 \mathrm{~g} / \mathrm{day}$ is relatively safe, yielding few side effects with the exception of a few subjects who experience nausea and drowsiness. The Commission $\mathrm{E}$ `approved the internal use of ginger for dyspepsia and prevention of motion sickness. Powdered rhizome, $0.25-1.0 \mathrm{~g}$, three times daily' (Bundesinstitut fur Arzneimittel und Medizinprodukte, 1998). AHPA-BSH recommends not exceeding the recommended 2-4 g/day, also warning against long term use or using during pregnancy (McGuffin, 1997).

\section{Potent plant extracts lacking reported safety evaluation}

Dryopteris Male Fern Rhizome (Dryopteris crassirhizoma) $\left(\mathrm{LC}_{50}=0.232 \mathrm{mg} / \mathrm{mL}\right.$ ) has been used historically to treat tapeworms and influenza. The plant contains kaempferol glycosides which are known to impair DNA polymerase which could possibly contribute in part to its anticancer effects. Alcohol extracts of this plant inhibit fatty acid synthase at low concentrations $(50 \mu \mathrm{g} / \mathrm{mL})$, an enzyme highly expressed in cancer tissue, and can antagonize the growth of cancer through down-regulation of PI3K/AKt and JNK pathways, S-phase arrest and induce apoptosis in cancer cell lines (Na et al., 2006; Zhao et al., 2006; Chiang et al., 2005). However, with little research to support safety and indication as to potential side effects of this herb it will require further research. This study also examines the resin from the fruit of Dragon's blood (Calamus draco) $\left(\mathrm{LC}_{50}=0.242 \mathrm{mg} / \mathrm{mL}\right.$ ). Dragon's blood has a potential application for cancer where an extract of Daemomorops draco contains the active constituent (dracorhodin) which induces proapoptotic tumoricidal affects in vitro (Xia et al., 2006). Although the traditional use of this resin has been as a coloring agent in varnishes, lacquers and plasters and incense, relatively few studies have been conducted to investigate potential safety issues with internal use. Red sandalwood (Pterocarpus santalinusis) $\left(\mathrm{LC}_{50}=\right.$ $0.326 \mathrm{mg} / \mathrm{mL}$ ) has generally proven effective in experimental models of diabetes and wound healing. However, the use of sandalwood oil is known to prevent 7,12dimethylbenz(a)anthracene-(DMBA)-initiated and 12-O-tetradecanoyl phorbol-13-acetate (TPA)-promoted skin papillomas in mice (Dwivedi and Abu-Ghazaleh, 1997). Red sandalwood is an AHPA-BSH 'Class 1 herb', with little known about the side effects associated with use, independent from reported topical dermatitis in susceptible individuals (McGuffin, 1997). However, until further studies are conducted to determine safety regarding internal use, this herb warrants caution with use.

Bushy Knotweed Rhizome (Polygonum Cuspidatum) $\left(\mathrm{LC}_{50}=0.361 \mathrm{mg} / \mathrm{mL}\right.$ ) is far from an endangered species, classified as an unwanted invasive, noxious weed which grows aggressively, survives in adverse climates and dominates ever expanding habitation and 
vegetative life, even to the point of creating an economic threat. Yet this is a plant that may offer of superb anticancer properties. Previously reported medicinal properties include its use as a potential cholesterol lowering agent, antibacterial, antiviral/HIV and estrogenic agent. Although the extract of this plant has not yet been examined for its anticancer properties, 3,4'-dimethoxy-5-hydroxystilbene which was obtained by methylation/acid hydrolysis of resveratrol-3-O-glucoside induces apoptosis in human promyelocytic leukemic HL-60 cells (Lee et al., 2002). Likewise, another compound inherent to the herb (resveratrol) is generally known to induce pro-apoptotic/antiproliferative effects on cancer cells through inhibition of nuclear factor-kappa B, COX-2 of which its oral administration at low dose was effective against 7,12-dimethylbenz(a)anthracene (DMBA) mammary carcinogenesis in female Sprague Dawley rats (Banerjee et al., 2002).

\section{Potent plant extracts with known side effects}

Other herbal extracts while showing lethal effects on tumor cells may have serious toxic side effects on the mammalian host system as well. Examples include Buckthorn bark (Rhamnus cathartica) $\left(\mathrm{LC}_{50}=0.107 \mathrm{mg} / \mathrm{mL}\right)$ which can lead to intestinal cramping, electrolyte imbalance and abnormal liver changes (Lichtensteiger et al., 1997); Chaparral (Larrea tridentate $)\left(\mathrm{LC}_{50}=0.124 \mathrm{mg} / \mathrm{mL}\right)$ which has been linked to extensive liver damage, cystic renal disease and adenocarcinoma of the kidney (Alderman et al., 1994; Smith et al., 1994); alkanet root (Batschia canescens) $\left(\mathrm{LC}_{50}=0.138 \mathrm{mg} / \mathrm{mL}\right.$ ), a coloring agent used in oils, cosmetics, textiles and henna-based hair coloring products and Kochia Seed (Kochia scoparia) $\left(\mathrm{LC}_{50}=0.147 \mathrm{mg} / \mathrm{mL}\right)$ a noxious tumbleweed used as a livestock feed, both induce hepatotoxicity, the former which contains toxic pyrrolizidine alkaloids and the latter containing toxic saponins, oxalates and nitrates (Rankins et al., 1991). Oral administration of Blue cohosh (Caulophyllum thalictroidesis) $\left(\mathrm{LC}_{50}=0.218 \mathrm{mg} / \mathrm{mL}\right.$ ) can be dangerous, also being linked with an increased likelihood of myocardial infarction, tachycardia, muscle weakness and stroke (Jones and Lawson, 1998). Also, the UK Committee on Safety of Medicines warns that traditional Chinese medicines that contain Psoralea fruit (Psoralea corylifolia) $\left(\mathrm{LC}_{50}=0.243 \mathrm{mg} / \mathrm{mL}\right)$ should not be used due to a risk of internal, external burning, allergic responses and phototoxicity. Senna leaf (Senna alexandria) $\left(\mathrm{LC}_{50}=0.275\right.$ $\mathrm{mg} / \mathrm{mL}$ ) a known laxative, promotes bowel movement leading to the relief of constipation. However, excessive intake may actually increase the risk of colon cancer (Mascolo et al., 1999) in addition to causing liver damage (Sonmez et al., 2005). Cubeb berry and black pepper derived from the Piper genus $\left(\mathrm{LC}_{50}=0.263 \mathrm{mg} / \mathrm{mL}\right)$, has a long touted historical application having both use as a food spice and medicinally to maintain the health of urinary tract, prostate and to treat dysentery, gonorrhea, bronchitis, hepatitis, inflammation and pain.

While a number of studies suggest that black pepper has anticancer properties, numerous reports have emerged suggesting that various portions of Piper nigrum plant, as well as its inherent constituents, safrole and tannic acid, can induce tumors and magnify the proliferation of malignant cells (Shwaireb et al., 1990). Feverfew (Tanacetum parthenium) also has a host of medicinal properties which include prophylaxis of migraine, antiinflammatory, antithrombotic effects and antitumor effects. However, feverfew also contains parthenolide which is cross-reactive with ragweed pollen to which $10-20 \%$ of the population may experience an allergic response (Sriramaro and Rao, 1993). Mace (Myristica fragans) $\left(\mathrm{LC}_{50}=0.271 \mathrm{mg} / \mathrm{mL}\right)$, another cooking spice, is derived from the same plant as nutmeg, often integral to the preparation of doughnuts, stews, baked goods, sauces and candy. Oral administration of mace has shown to be protective against chemically induced cancer such as DMBA-induced papillomagenesis in mice (Jannu et al., 1991) and active ingredients within nutmeg such as dihydroguaiaretic acid or myristicin inhibit the proliferation of a variety of cancer cell lines including leukemia, lung and colon cancer (Park et al., 1998). While intake is relatively safe at a low dose, due to the potential serious 
side effects of nutmeg/mace overdose ( $5 \mathrm{~g} /$ day) including psychological hallucinations, delusions, dizziness, psychosis and sedation, coma and death, intake of this herb should be limited to a low quantity (McGuffin, 1997; Kelly et al., 2003). Eucalyptus leaf (Eucalyptus globules) $\left(\mathrm{LC}_{50}=0.305 \mathrm{mg} / \mathrm{mL}\right)$ has also been linked to warnings issued based on the internal use of oil extracts causing convulsions, nausea, vomiting, a drop in blood pressure, poisoning and death. Unlike the oil, aqueous extracts are commonly used for treating colds, headaches, flu, bronchial infection, arthritis and pain. According to the Germany's Commission E report, contraindications for the use of this herb also include adverse effects on the gastrointestinal tract, bile ducts and the liver (Bundesinstitut fur Arzneimittel und Medizinprodukte, 1998) and as such is also classified as a AHPA-BSH Class 2 herb (McGuffin, 1997).

Wild cherry bark (Prunus serotina) $\left(\mathrm{LC}_{50}=0.360 \mathrm{mg} / \mathrm{mL}\right.$ ) is known to exert anticancer properties as shown here and confirmed by the findings of Yamaguchi et al., who recently demonstrated that the extract had antiproliferative effects via down-regulation of cyclin D1 expression in human colorectal cancer cells (Yamaguchi et al., 2006). However, the bark may also contain trace levels $(0.5 \%)$ of hydrogen cyanide (poison), similar to that of apricot and peach pits and should not be used by pregnant women or individuals who have preexisting liver or kidney diseases (McGuffin, 1997). Yellow Dock root (Rumex crispus) $\left(\mathrm{LC}_{50}=0.348 \mathrm{mg} / \mathrm{mL}\right)$ has been used as a remedy for chronic skin conditions, psoriasis, constipation, anemia, jaundice and to improve the general health and function of the liver and lymph. However, caution should be advised with use due to potential allergic reactions and side effects including hypocalcemia, metabolic acidosis, liver and kidney damage, tremor, ataxia and death in mammals (Panciera et al., 1990; Reig et al., 1990). Yellow dock is an AHPA-BSH 'Class 2 herb', with warnings that due to the oxalate content within this herb it is counter-indicated in individuals with kidney stones (McGuffin, 1997). Birch leaf (Betula alba) $\left(\mathrm{LC}_{50}=0.365 \mathrm{mg} / \mathrm{mL}\right)$ is often used in the form of a tea, taken as a diuretic to flush out and restore the function of the kidney and bladder. Recommended use is 5-10 g of cut leaves in boiled water per day, however, while generally safe, due to the potential allergic response that occurs with pollen of this plant (Lahti and Hannuksela, 1980), this herb also warrants caution with use specifically for individuals who have allergies.

Cinnamon (Cinnamomum cassia) $\left(\mathrm{LC}_{50}=0.479 \mathrm{mg} / \mathrm{mL}\right.$ ), another cooking spice, has a host of medicinal therapeutic properties which include anticancer effects, however, its inherent allergic and irritant properties can lead to contact stomatitis in sensitive individuals (Bousquet et al., 2005). The Commission E has `approved the internal use of cinnamon for loss of appetite and dyspeptic complaints such as mild spasms of the gastrointestinal tract, bloating and flatulence. And, unless otherwise prescribed, $2-4 \mathrm{~g}$ per day of ground bark is deemed acceptable' (Bundesinstitut fur Arzneimittel und Medizinprodukte, 1998). However, cinnamon is a AHPA-BSH Class 2 herb and should not be used for long term use, should not exceed an intake of 2-4 g per day and not be taken during pregnancy (McGuffin, 1997).

Turkey rhubarb (Rheum palmate) $\left(\mathrm{LC}_{50}=0.466 \mathrm{mg} / \mathrm{mL}\right.$ ) has extensive historical use in a wide range of applications such as treatment of constipation, high cholesterol and renal failure. Rhubarb contains a number of anticancer hydroxyanthraquinones and anthraquinone glycosides which exert antiproliferative/anticancer effects, and whole extract shows mild antimutagenic properties (Edenharder et al., 1990). However, excessive oral intake can be poisonous (Sanz and Reig, 1992), where the oxalate content of the plant can bind metals leading to iron deficiencies, anemia and electrolyte imbalances. Further, its use is warned against with individuals who have kidney stones (Massey et al., 1993). AHPA-BSH has placed this herb under Class 2, due to the high oxalate content contraindicated in intestinal obstruction, in children under 12 years of age and not recommended for long term use (McGuffin, 1997). Elecampane root (Inula helenium) $\left(\mathrm{LC}_{50}=0.379 \mathrm{mg} / \mathrm{mL}\right.$ ) has extended 
the historical use for treatment of colds, flu, respiratory, fungal/bacterial/parasitic infections, pain, animal bites and skin ailments. The primary constituents of this plant are inula, inulin and helenin and while several studies show great potential of this herb in espousing anticancer effects in a variety of cancer cell lines (Dorn et al., 2006) due to the potential allergic response that occurs to the chemical alantolactone, this herb also requires further research regarding safety (Paulsen, 2002).

Lastly, the use of White Sage (Salvia apiana) $\left(\mathrm{LC}_{50}=0.299 \mathrm{mg} / \mathrm{mL}\right)$ and similar plants inherent to the botanical genus Salvia date back to 1400 A.D. as a food preservative, flavoring, and medicinal agent to treat headaches, pains, indigestion, heart disease, colds and influenza. Alcohol extracts of sage demonstrate a diverse range of beneficial properties much attributed to inherent polyphenolics, rosmarinic acid, camphor and carnasol which yield antiinflammatory, antioxidant, antimalarial, antibacterial and antifungal effects. In animals, alcohol extracts of sage can be lethal to rodents when administered at very high concentrations equal to or above $3000 \mathrm{mg} / \mathrm{kg}$ (Eidi et al., 2005) and the essential oil of sage under various seasonal conditions is known to have an $\mathrm{LD}_{50}$ at above $800 \mathrm{mg} / \mathrm{kg}$ in mice (Farhat et al., 2001). At lower doses, however, oral administration of sage tea in the drinking water (approximately $10 \mathrm{mg} / \mathrm{kg}$ ) was found safe and effective in providing hepatoprotective effects and a reduction in BHt-induced lipid peroxidation in hepatocytes (Lima et al., 2005). Toxicity associated with sage is associated with the oil of sage, which can induce hypoglycemia, tachycardia, convulsions, muscle cramps and respiratory disorders (GaliMuhtasib et al., 2000). The Commission E has `approved the internal use of sage leaf for dyspeptic symptoms and excessive perspiration, and external use for inflammations of the mucous membranes of nose and throat with recommended dry leaf intake, 1-3 g, three times daily or fluid extract $1,1(\mathrm{~g} / \mathrm{mL}), 1-3 \mathrm{~mL}$, three times daily' (Bundesinstitut fur Arzneimittel und Medizinprodukte, 1998). Sage is none the less classified as a AHPA-BSH Class $2 b$ herb, not advised for long term use or during pregnancy, and not to exceed the recommended dose of 4-6 g daily (McGuffin, 1997).

In summary, these findings demonstrate a host of potentially new identified plants and roots which can be further explored for anticancer constituents and properties that may provide CAM strategies for cancer patients or derive future chemotherapy drugs.

\section{REFERENCES}

Advance Data from Vital and Health Statistics. CDC. May 27. 2004

Alderman S, Kailas S, Goldfarb S, Singaram C, Malone DG. Cholestatic hepatitis after ingestion of chaparral leaf, confirmation by endoscopic retrograde cholangiopancreatography and liver biopsy. J Clin Gastroenterol 1994;19:242-247. [PubMed: 7806838]

Banerjee S, Bueso-Ramos C, Aggarwal BB. Suppression of 7,12-dimethylbenz(a)anthracene-induced mammary carcinogenesis in rats by resveratrol, role of nuclear factor-kappaB, cyclooxygenase 2, and matrix metalloprotease 9. Cancer Res 2002;62:4945-4954. [PubMed: 12208745]

Blackburn GL, Wang KA. Dietary fat reduction and breast cancer outcome: results from the Women's Intervention Nutrition Study (WINS). Am J Clin Nutr 2007;86:s878-s881. [PubMed: 18265482]

Blot WJ. Vitamin/mineral supplementation and cancer risk: international chemoprevention trials. Proc Soc Exp Biol Med 1997;216:291-296. [PubMed: 9349699]

Bousquet PJ, Guillot B, Guilhou JJ, Raison-Peyron N. A stomatitis due to artificial cinnamon-flavored chewing gum. Arch Dermatol 2005;141:1466-1467. [PubMed: 16301399]

Bundesinstitut fur Arzneimittel und Medizinprodukte. The Complete German Commission E Monographs, Therapeutic Guide to Herbal Medicines. Lippincott Williams \& Wilkins; 1998. Herbalgram online database 
Calviello G, Serini S, Piccioni E. n-3 polyunsaturated fatty acids and the prevention of colorectal cancer: molecular mechanisms involved. Curr Med Chem 2007;14:3059-3069. [PubMed: 18220742]

Chakraborty S, Roy M, Taraphdar AK, Bhattacharya RK. Cytotoxic effect of root extract of Tiliacora racemosa and oil of Semecarpus anacardium nut in human tumour cells. Phytother Res 2004;18:595-600. [PubMed: 15476314]

Chiang CT, Weng MS, Lin-Shiau SY, Kuo KL, Tsai YJ, Lin JK. Pu-erh tea supplementation suppresses fatty acid synthase expression in the rat liver through downregulating Akt and JNK signalings as demonstrated in human hepatoma HepG2 cells. Oncol Res 2005;16:119-128. [PubMed: 16925113]

Conney AH. Enzyme induction and dietary chemicals as approaches to cancer chemoprevention: the Seventh DeWitt S. Goodman Lecture. Cancer Res 2003;63:7005-7031. [PubMed: 14612489]

Dorn DC, Alexenizer M, Hengstler JG, Dorn A. Tumor cell specific toxicity of Inula helenium extracts. Phytother Res 2006;20:970-980. [PubMed: 16912983]

Dorrie J, Sapala K, Zunino SJ. Carnosol-induced apoptosis and downregulation of Bcl-2 in B-lineage leukemia cells. Cancer Lett 2001;170:33-39. [PubMed: 11448532]

Dr Dukes Phytochemical and Ethnobotanical Databases. http://www.ars-grin.gov/duke/http://www.arsgrin.gov/duke/

Dwivedi C, Abu-Ghazaleh A. Chemopreventive effects of sandalwood oil on skin papillomas in mice. Eur J Cancer Prev 1997;6:399-401. [PubMed: 9370104]

Dy GK, Bekele L, Hanson LJ, et al. Complementary and alternative medicine use by patients enrolled onto phase I clinical trials. J Clin Oncol 2004;22:4810-4815. [PubMed: 15570083]

Edenharder R, John K, Ivo-Boor H. Antimutagenic activity of vegetable and fruit extracts against in vitro benzo(a)pyrene. Z Gesamte Hyg 1990;36:144-147. [PubMed: 2336853]

Eidi M, Eidi A, Zamanizadeh H. Effect of Salvia officinalis L. leaves on serum glucose and insulin in healthy and streptozotocin-induced diabetic rats. J Ethnopharmacol 2005;100:310-313. [PubMed: 16125023]

Farhat GN, Affara NI, Gali-Muhtasib HU. Seasonal changes in the composition of the essential oil extract of East Mediterranean sage (Salvia libanotica) and its toxicity in mice. Toxicon 2001;39:1601-1605. [PubMed: 11478969]

Finklestein JZ, Tittle K, Meshnik R, Weiner J. Murine neuroblastoma, further evaluation of the C1300 model with single antitumor agents. Cancer Chemother Rep 1975;59:975-983. [PubMed: 1203900]

Frankos VH, Brusick DJ, Johnson EM, et al. Safety of Sanguinaria extract as used in commercial toothpaste and oral rinse products. J Can Dent Assoc 1990;56(7 Suppl):41-47. [PubMed: 2207854]

Gali-Muhtasib H, Hilan C, Khater C. Traditional uses of Salvia libanotica (East Mediterranean sage) and the effects of its essential oils. J Ethnopharmacol 2000;71:513-520. [PubMed: 10940591]

Gerson-Cwilich R, Serrano-Olvera A, Villalobos-Prieto A. Complementary and alternative medicine (CAM) in Mexican patients with cancer. Clin Transl Oncol 2006;8:200-207. [PubMed: 16648120]

Govindan S, Viswanathan S, Vijayasekaran V, Alagappan R. Further studies on the clinical efficacy of Solanum xanthocarpum and Solanum trilobatum in bronchial asthma. Phytother Res 2004;18:805809. [PubMed: 15551394]

Graf TN, Levine KE, Andrews ME, et al. Variability in the yield of benzophenanthridine alkaloids in wildcrafted vs cultivated bloodroot (Sanguinaria canadensis L.). J Agric Food Chem 2007;55:1205-1211. [PubMed: 17253712]

Guo QL, You QD, Wu ZQ, Yuan ST, Zhao L. General gambogic acids inhibited growth of human hepatoma SMMC-7721 cells in vitro and in nude mice. Acta Pharmacol Sin 2004;25:769-774. [PubMed: 15169630]

Hanus LO, Rezanka T, Dembitsky VM, Moussaieff A. Myrrh - Commiphora chemistry. Biomed Pap Med Fac Univ Palacky Olomouc Czech Repub 2005;149:3-27. [PubMed: 16170385]

Hernandez BY, McDuffie K, Wilkens LR, Kamemoto L, Goodman MT. Diet and premalignant lesions of the cervix: evidence of a protective role for folate, riboflavin, thiamin, and vitamin B12. Cancer Causes Control 2003;14:859-870. [PubMed: 14682443] 
Hillson RM. Gold, frankincense and myrrh. J R Soc Med 1988;81:542-543. [PubMed: 3054109]

Hostanska K, Daum G, Saller R. Cytostatic and apoptosisinducing activity of boswellic acids toward malignant cell lines in vitro. Anticancer Res 2002;22:2853-2862. [PubMed: 12530009]

Hu Z, Yang X, Ho PC, et al. Herb-drug interactions, a literature review. Drugs 2005;65:1239-1282. [PubMed: 15916450]

Isidorov VA, Vinogorova VT. GC-MS analysis of compounds extracted from buds of Populus balsamifera and Populus nigra. Z Naturforsch 2003;58:355-360.

Jannu LN, Hussain SP, Rao AR. Chemopreventive action of mace (Myristica fragrans, Houtt) on DMBA-induced papillomagenesis in the skin of mice. Cancer Lett 1991;56:59-63. [PubMed: 1900737]

Jerković I, Mastelić J. Volatile compounds from leaf-buds of Populus nigra L (Salicaceae). Phytochemistry 2003;63:109-113. [PubMed: 12657305]

Jones TK, Lawson BM. Profound neonatal congestive heart failure caused by maternal consumption of blue cohosh herbal medication. J Pediatr 1998;132:550-552. [PubMed: 9544922]

Kelly BD, Gavin BE, Clarke M, Lane A, Larkin C. Nutmeg and psychosis. Schizophr Res 2003;60:95-96. [PubMed: 12505144]

Kelly KM. Complementary and alternative medical therapies for children with cancer. Eur J Cancer 2004;40:2041-2046. [PubMed: 15341976]

Klebe RJ, Ruddle FH. Neuroblastoma, cell culture analysis of a differentiating stem cell system. J Cell Biol 1969;43:69A.

Kumar NB, Allen K, Bell H. Perioperative herbal supplement use in cancer patients, potential implications and recommendations for presurgical screening. Cancer Control 2005;12:149-157. [PubMed: 16062162]

Lahti A, Hannuksela M. Immediate contact allergy to birch leaves and sap. Contact Dermatitis 1980;6:464-465. [PubMed: 7214889]

Lee SH, Ryu SY, Kim HB, Kim MY, Chun YJ. Induction of apoptosis by 3,4'-dimethoxy-5hydroxystilbene in human promyeloid leukemic HL-60 cells. Planta Med 2002;68:123-127. [PubMed: 11859461]

Leger DY, Liagre B, Beneytout JL. Role of MAPKs and NFkappaB in diosgenin-induced megakaryocytic differentiation and subsequent apoptosis in HEL cells. Int J Oncol 2006;28:201207. [PubMed: 16327997]

Liagre B, Bertrand J, Leger DY, Beneytout JL. Diosgenin, a plant steroid, induces apoptosis in COX-2 deficient K562 cells with activation of the p38 MAP kinase signalling and inhibition of NFkappaB binding. Int J Mol Med 2005;16:1095-1101. [PubMed: 16273292]

Liao CH, Sang S, Ho CT, Lin JK. Garcinol modulates tyrosine phosphorylation of FAK and subsequently induces apoptosis through down-regulation of Src, ERK, and Akt survival signaling in human colon cancer cells. J Cell Biochem 2005;96:155-169. [PubMed: 16052481]

Lichtensteiger CA, Johnston NA, Beasley VR. Rhamnus cathartica (buckthorn) hepatocellular toxicity in mice. Toxicol Pathol 1997;25:449-452. [PubMed: 9323832]

Lima CF, Andrade PB, Seabra RM, Fernandes-Ferreira M, Pereira-Wilson CJ. The drinking of a Salvia officinalis infusion improves liver antioxidant status in mice and rats. Ethnopharmacology 2005;97:383-389. [PubMed: 15707779]

Lin JH. Applications and limitations of interspecies scaling and in vitro extrapolation in pharmacokinetics. Drug Metab Dispos 1998;26:1202-1212. [PubMed: 9860929]

Liu JJ, Nilsson A, Oredsson S, Badmaev V, Zhao WZ, Duan RD. Boswellic acids trigger apoptosis via a pathway dependent on caspase-8 activation but independent on Fas/Fas ligand interaction in colon cancer HT-29 cells. Carcinogenesis 2002;23:2087-2093. [PubMed: 12507932]

Liu W, Guo QL, You QD, Zhao L, Gu HY, Yuan ST. Anticancer effect and apoptosis induction of gambogic acid in human gastric cancer line BGC-823. World J Gastroenterol 2005;11:3655-3659. [PubMed: 15968715]

Mascolo N, Mereto E, Borrelli F, et al. Does senna extract promote growth of aberrant crypt foci and malignant tumors in rat colon? Dig Dis Sci 1999;44:2226-2230. [PubMed: 10573366] 
Massey LK, Roman-Smith H, Sutton RA. Effect of dietary oxalate and calcium on urinary oxalate and risk of formation of calcium oxalate kidney stones. J Am Diet Assoc 1993;93:901-906. [PubMed: 8335871]

Matsumoto K, Akao Y, Kobayashi E, et al. Cytotoxic benzophenone derivatives from Garcinia species display a strong apoptosis-inducing effect against human leukemia cell lines. Biol Pharm Bull 2003;26:569-571. [PubMed: 12673047]

Mazzio E, Yoon KJ, Soliman KF. Acetyl-L-carnitine cytoprotection against 1-methyl-4phenylpyridinium toxicity in neuroblastoma cells. Biochem Pharmacol 2003;66:297-306. [PubMed: 12826272]

McDaniel S, Goldman GD. Consequences of using escharotic agents as primary treatment for nonmelanoma skin cancer. Arch Dermatol 2002;138:1593-1596. [PubMed: 12472348]

McGuffin, M. American Herbal Products Association's Botanical Safety Handbook. CRC Pr Inc; Boca Raton, Florida, USA: 1997.

Melnick SJ. Developmental therapeutics, review of biologically based CAM therapies for potential application in children with cancer, part I. J Pediatr Hematol Oncol 2006;28:221-230. [PubMed: 16679919]

Molassiotis A, Browall M, Milovics L, Panteli V, Patiraki E, Fernandez-Ortega P. Complementary and alternative medicine use in patients with gynecological cancers in Europe. Int J Gynecol Cancer 2006;16(Suppl 1):219-224. [PubMed: 16515594]

Moran AE, Carothers AM, Weyant MJ, Redston M, Bertagnolli MM. Carnosol inhibits beta-catenin tyrosine phosphorylation and prevents adenoma formation in the C57BL/6J/Min/+ (Min/+) mouse. Cancer Res 2005;65:1097-1104. [PubMed: 15705912]

$\mathrm{Na}$ M, Jang J, Min BS, et al. Fatty acid synthase inhibitory activity of acylphloroglucinols isolated from Dryopteris crassirhizoma. Bioorg Med Chem Lett 2006;16:4738-4742. [PubMed: 16870425]

Nabandith V, Suzui M, Morioka T, et al. Inhibitory effects of crude alpha-mangostin, a xanthone derivative, on two different categories of colon preneoplastic lesions induced by 1,2dimethylhydrazine in the rat. Asian Pac J Cancer Prev 2004;5:433-438. [PubMed: 15546251]

Nagasawa H, Watanabe K, Inatomi H. Effects of bitter melon (Momordica charantia L.) or ginger rhizome (Zingiber officinale Rosc.) on spontaneous mammary tumorigenesis in SHN mice. Am J Chin Med 2002;30:195-205. [PubMed: 12230008]

Final report of the amended safety assessment of Dioscorea villosa (Wild Yam) root extract. Int J Toxicol 2004;23(Suppl 2):49-54. No authors listed. [PubMed: 15513824]

Ohyama K, Akaike T, Hirobe C, Yamakawa T. Cytotoxicity and apoptotic inducibility of Vitex agnuscastus fruit extract in cultured human normal and cancer cells and effect on growth. Biol Pharm Bull 2003;26:10-18. [PubMed: 12520164]

Ohyama K, Akaike T, Imai M, Toyoda H, Hirobe C, Bessho T. Human gastric signet ring carcinoma (KATO-III) cell apoptosis induced by Vitex agnus-castus fruit extract through intracellular oxidative stress. Int J Biochem Cell Biol 2005;37:1496-1510. [PubMed: 15833280]

Omer SA, Adam SE, Khalid HE. Effects on rats of Commiphora myrrha extract given by different routes of administration. Vet Hum Toxicol 1999;41:193-196. [PubMed: 10434369]

Pan MH, Chang WL, Lin-Shiau SY, Ho CT, Lin JK. Induction of apoptosis by garcinol and curcumin through cytochrome c release and activation of caspases in human leukemia HL-60 cells. J Agric Food Chem 2001;49:1464-1474. [PubMed: 11312881]

Panciera RJ, Martin T, Burrows GE, Taylor DS, Rice LE. Acute oxalate poisoning attributable to ingestion of curly dock (Rumex crispus) in sheep. J Am Vet Med Assoc 1990;196:1981-1984. [PubMed: 2365622]

Park S, Lee DK, Yang CH. Inhibition of fos-jun-DNA complex formation by dihydroguaiaretic acid and in vitro cytotoxic effects on cancer cells. Cancer Lett 1998;127:23-28. [PubMed: 9619854]

Paulsen E. Contact sensitization from Compositae-containing herbal remedies and cosmetics. Contact Dermatitis 2002;47:189-198. [PubMed: 12492516]

Plouzek CA, Ciolino HP, Clarke R, Yeh GC. Inhibition of P-glycoprotein activity and reversal of multidrug resistance in vitro by rosemary extract. Eur J Cancer 1999;35:1541-1545. [PubMed: 10673984] 
Qureshi S, al-Harbi MM, Ahmed MM, Raza M, Giangreco AB, Shah AH. Evaluation of the genotoxic, cytotoxic, and antitumor properties of Commiphora molmol using normal and Ehrlich ascites carcinoma cell-bearing Swiss albino mice. Cancer Chemother Pharmacol 1993;33:130-138. [PubMed: 8261571]

Rankins DL Jr, Smith GS, Hallford DM. Altered metabolic hormones, impaired nitrogen retention, and hepatotoxicosis in lambs fed Kochia scoparia hay. J Anim Sci 1991;69:2932-2940. [PubMed: 1885402]

Reig R, Sanz P, Blanche C, Fontarnau R, Dominguez A, Corbella J. Fatal poisoning by Rumex crispus (curled dock), pathological findings and application of scanning electron microscopy. Vet Hum Toxicol 1990;32:468-470. [PubMed: 2238449]

Rosenberg Zand RS, Jenkins DJ, Diamandis EP. Flavonoids and steroid hormone-dependent cancers. J Chromatogr B Analyt Technol Biomed Life Sci 2002;777:219-232.

Sanz P, Reig R. Clinical and pathological findings in fatal plant oxalosis. A review. Am J Forensic Med Pathol 1992;13:342-345. [PubMed: 1288268]

Scott JA, Kearney N, Hummerston S, Molassiotis A. Use of complementary and alternative medicine in patients with cancer: a UK survey. Eur J Oncol Nurs 2005;9:131-137. [PubMed: 15944106]

Seifen E, Adams RJ, Riemer RK. Sanguinarine, a positive inotropic alkaloid which inhibits cardiac Na ${ }^{+}, \mathrm{K}^{+}$-ATPase. Eur J Pharmacol 1979;60:373-377. [PubMed: 230984]

Sheir Z, Nasr AA, Massoud A, et al. A safe, effective, herbal antischistosomal therapy derived from myrrh. Am J Trop Med Hyg 2001;65:700-704. [PubMed: 11791960]

Shishodia S, Aggarwal BB. Diosgenin inhibits osteoclastogenesis, invasion, and proliferation through the downregulation of Akt, I kappa B kinase activation and NF-kappa B-regulated gene expression. Oncogene 2006;25:1463-1473. [PubMed: 16331273]

Shoemaker M, Hamilton B, Dairkee SH, Cohen I, Campbell MJ. In vitro anticancer activity of twelve Chinese medicinal herbs. Phytother Res 2005;19:649-651. [PubMed: 16161030]

Shwaireb MH, Wrba H, el-Mofty MM, Dutter A. Carcinogenesis induced by black pepper (Piper nigrum) and modulated by vitamin A. Exp Pathol 1990;40:233-238. [PubMed: 2098270]

Singletary K, MacDonald C, Wallig M. Inhibition by rosemary and carnosol of 7,12dimethylbenz[a]anthracene (DMBA)-induced rat mammary tumorigenesis and in vivo DMBADNA adduct formation. Cancer Lett 1996;104:43-48. [PubMed: 8640744]

Smith AY, Feddersen RM, Gardner KD Jr, Davis CJ Jr. Cystic renal cell carcinoma and acquired renal cystic disease associated with consumption of chaparral tea, a case report. J Urol 1994;152:20892091. [PubMed: 7966683]

Sonmez A, Yilmaz MI, Mas R, et al. Subacute cholestatic hepatitis likely related to the use of senna for chronic constipation. Acta Gastroenterol Belg 2005;68:385-387. [PubMed: 16268429]

Sriramarao P, Rao PV. Allergenic cross-reactivity between Parthenium and ragweed pollen allergens. Int Arch Allergy Immunol 1993;100:79-85. [PubMed: 8428168]

Suksamrarn S, Komutiban O, Ratananukul P, Chimnoi N, Lartpornmatulee N, Suksamrarn A. Cytotoxic prenylated xanthones from the young fruit of Garcinia mangostana. Chem Pharm Bull (Tokyo) 2006;54:301-305. [PubMed: 16508181]

Syrovets T, Buchele B, Gedig E, Slupsky JR, Simmet T. Acetyl-boswellic acids are novel catalytic inhibitors of human topoisomerases I and II alpha. Mol Pharmacol 2000;58:71-81. [PubMed: 10860928]

Tian XY, Wang YH, Liu HY, Yu SS, Fang WS. On the chemical constituents of Dipsacus asper. Chem Pharm Bull 2007;55:1677-1681. [PubMed: 18057739]

Wang LG, Liu XM, Ji XJ. Determination of DNA topoisomerase II activity from L1210 cells - a target for screening antitumor agents. Zhongguo Yao Li Xue Bao 1991;12:108-114. [PubMed: 1663690]

Wei QY, Ma JP, Cai YJ, Yang L, Liu ZL. Cytotoxic and apoptotic activities of diarylheptanoids and gingerol-related compounds from the rhizome of Chinese ginger. J Ethnopharmacol 2005;102:177-184. [PubMed: 16024193]

Xia MY, Wang MW, Cui Z, et al. Dracorhodin perchlorate induces apoptosis in HL-60 cells. J Asian Nat Prod Res 2006;8:335-343. [PubMed: 16864444] 
Yamaguchi K, Liggett JL, Kim NC, Baek SJ. Anti-proliferative effect of horehound leaf and wild cherry bark extracts on human colorectal cancer cells. Oncol Rep 2006;15:275-281. [PubMed: 16328068]

Yates JS, Mustian KM, Morrow GR, et al. Prevalence of complementary and alternative medicine use in cancer patients during treatment. Support Care Cancer 2005;13:806-811. [PubMed: 15711946]

Zhang HZ, Kasibhatla S, Wang Y, et al. Discovery, characterization and SAR of gambogic acid as a potent apoptosis inducer by a HTS assay. Bioorg Med Chem 2004;12:309-317. [PubMed: 14723951]

Zhang ZJ, Qian YH, Hu HT, Yang J, Yang GD. The herbal medicine Dipsacus asper wall extract reduces the cognitive deficits and overexpression of beta-amyloid protein induced by aluminum exposure. Life Sci 2003;73:2443-2454. [PubMed: 12954453]

Zhao W, Kridel S, Thorburn A, et al. Fatty acid synthase, a novel target for antiglioma therapy. Br J Cancer 2006;95:869-878. [PubMed: 16969344]

Zhou JY, Cui R. Chemical components of Boswellia carterii. Yao Xue Xue Bao 2002;37:633-635. [PubMed: 12567779] 

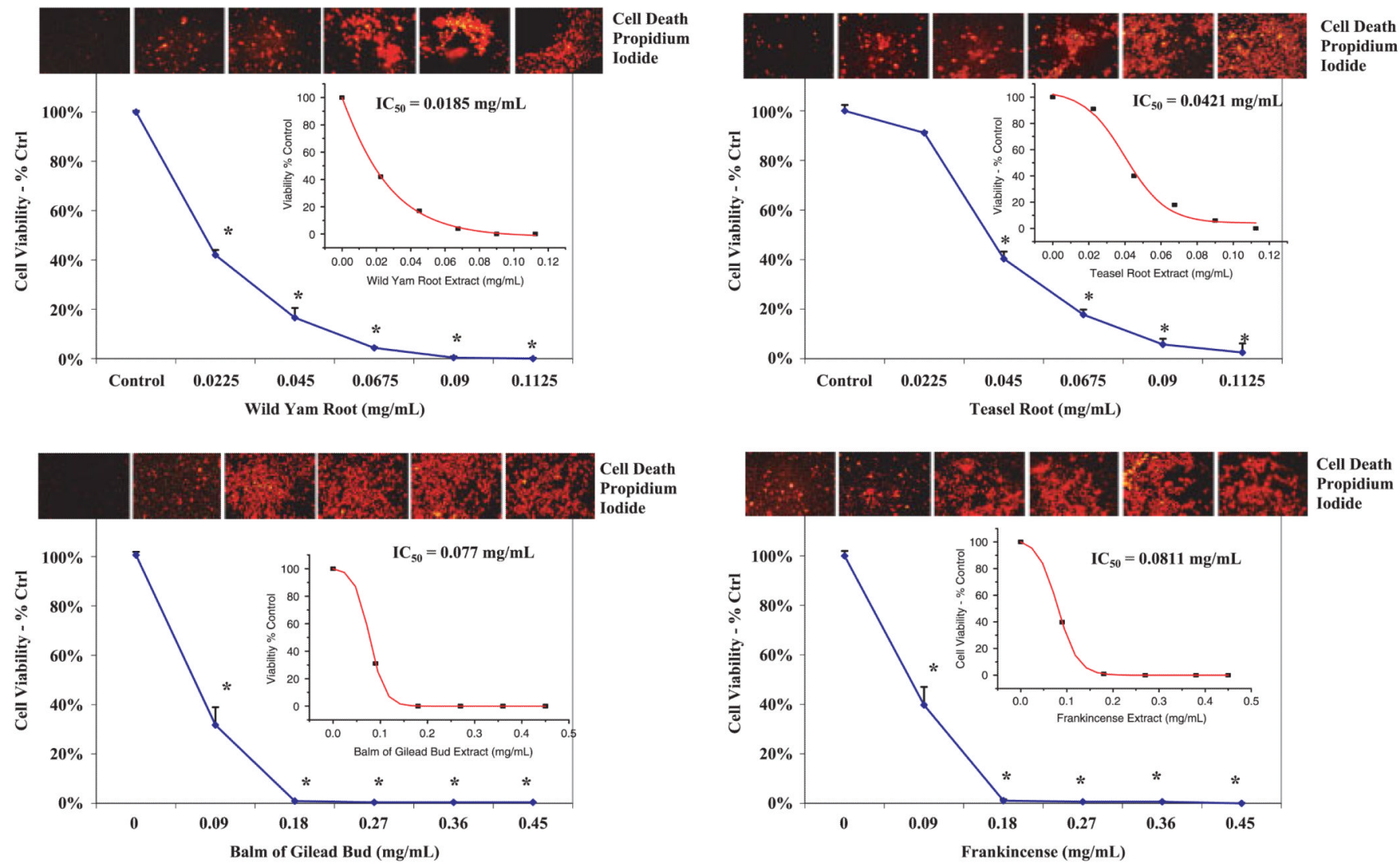

Cell Death Propidium Iodide
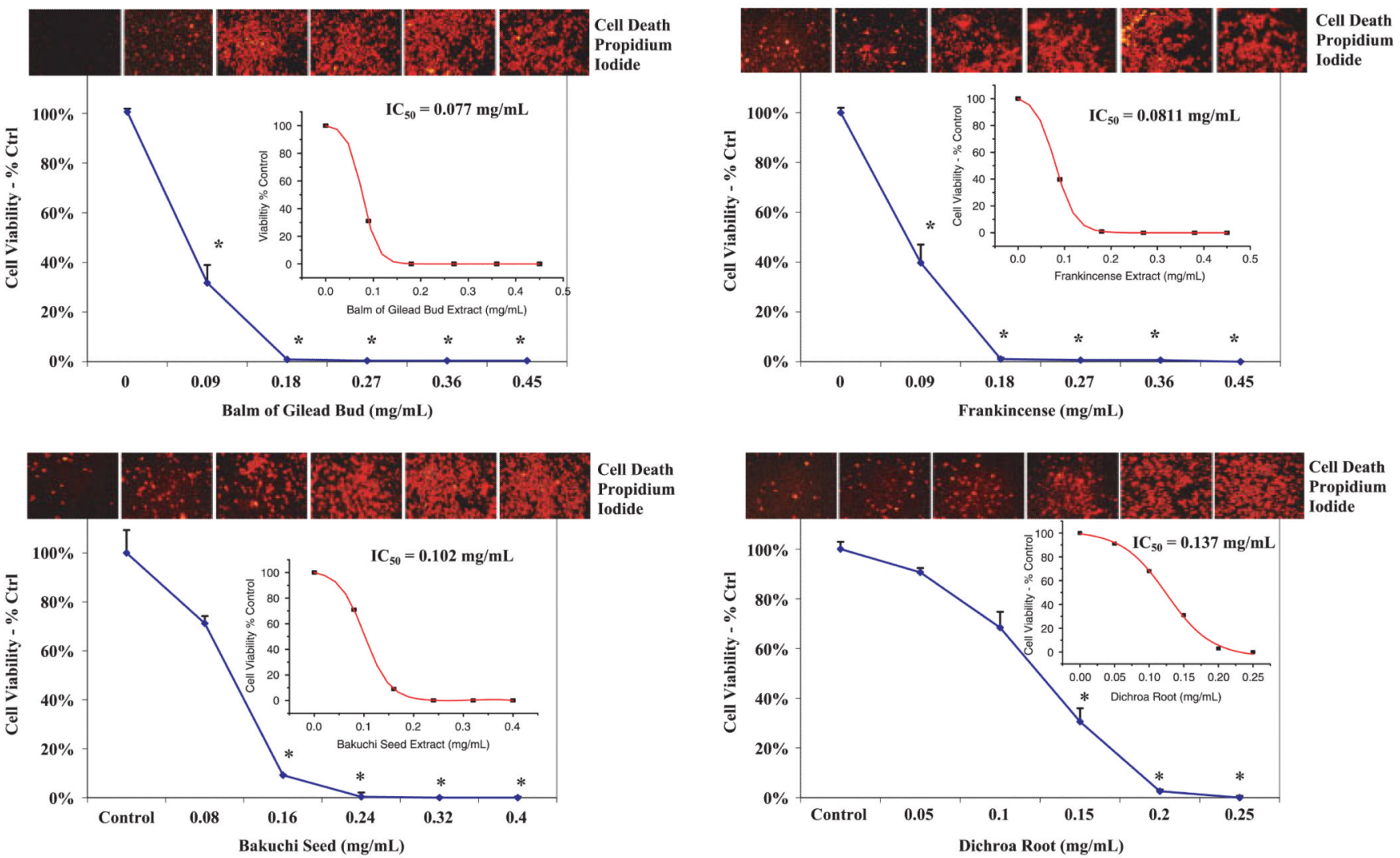

Phytother Res. Author manuscript; available in PMC 2009 March 3. 

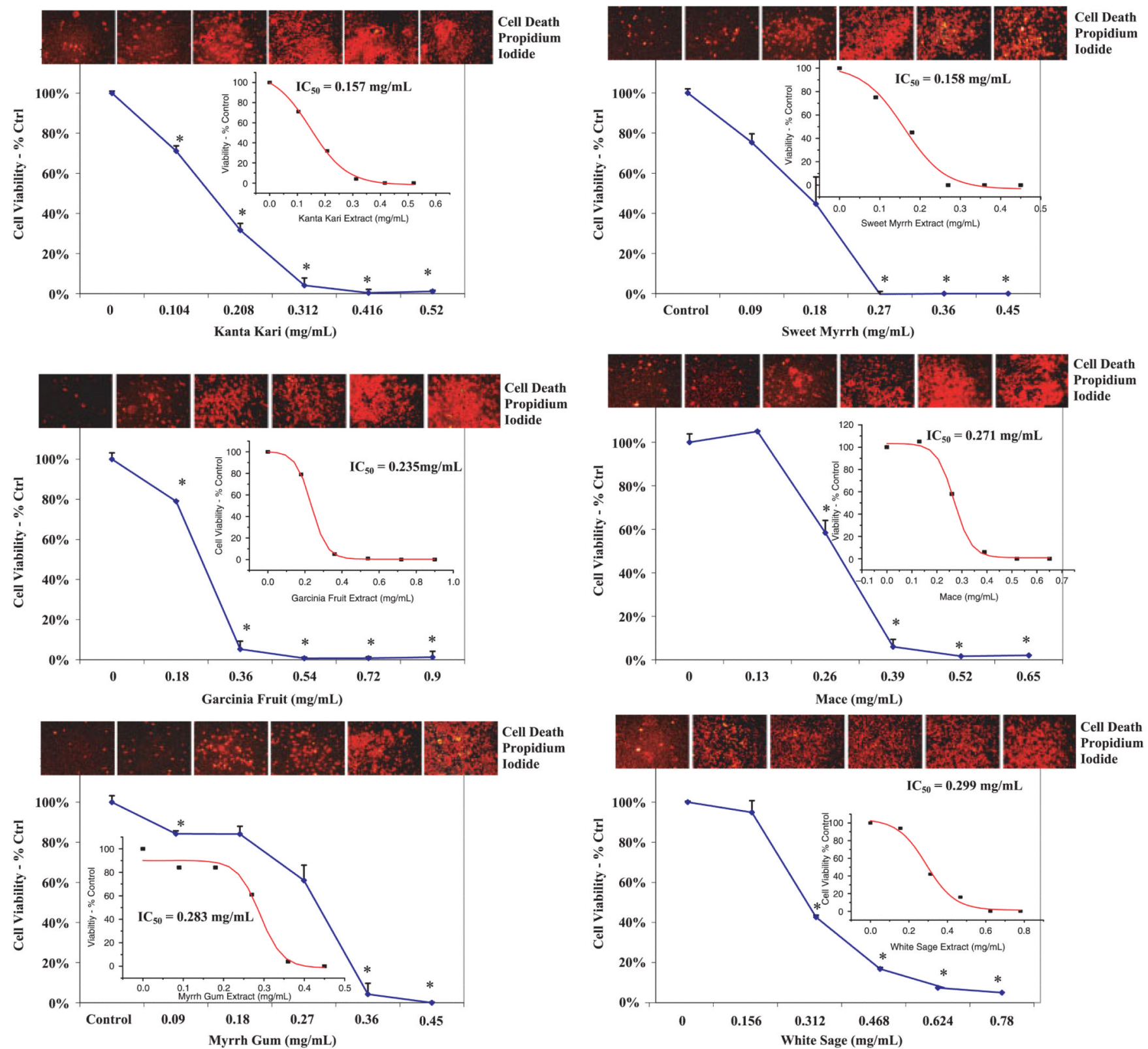

Figures 1-12.

The effect of most potent herbs on cell viability and death in murine neuroblastoma cells derived from a malignant spontaneous tumor. The data are expressed as the mean \pm SEM $(n$ $=4$ ), and represent viability as \% control. Photographic display of PI nuclear staining represents corresponding dose dependent cell death. This figure is available in colour online at www.interscience.wiley.com/journal/ptr 
Table 1

The effect of natural products on cell viability in murine neuroblastoma cell line originally derived from a spontaneous malignant tumor. The data represent the $\mathrm{LC}_{50}(\mathrm{mg} / \mathrm{mL})$ calculated from $6+$ concentrations spanning a thousand fold dilution range $(n=4)$

\begin{tabular}{|c|c|c|c|}
\hline \multicolumn{4}{|c|}{$\begin{array}{l}\text { TABLE 1A } \\
\text { ANTI-CANCER SCREEN - CATEGORY 1: STRONGEST }\end{array}$} \\
\hline \multicolumn{4}{|c|}{$\rightarrow \mathrm{LC}_{50}=[0.019-0.528 \mathrm{mg} / \mathrm{ml}] \rightarrow$} \\
\hline *Wild Yam [.019] & Dryopteris Male Fern Rhizome [.232] & Yellow Dock Root [.348] & Bhumy Amalaki [.497] \\
\hline Blood Root [.040] & ${ }^{*}$ Garcinia Fruit [.235] & Wild Cherry Bark [.360] & Butternut Bark [.506] \\
\hline *Teasel Root [.042] & Dragons Blood [.242] & *Bushy Knotweed Rhizome [.361] & $\underline{\text { Green Tea [.507] }}$ \\
\hline *Balm of Gilead Bud [.078] & Psoralea Fruit [.243] & Birch Leaf [.365] & Osho Root [.509] \\
\hline *Frankincence [.081] & Cubeb Berry [.263] & Elecampane Root [.397] & Redroot $[.514]$ \\
\hline *Bakuchi Seed [.102] & ${ }^{*}$ Mace [.271] & *Ginger Root [.447] & Gymnema [.517] \\
\hline Buckthorne Bark [.107] & Senna Leaf [.275] & ${ }^{*}$ Nutmeg [.447] & Superior Gun Powder [.518] \\
\hline Chaparral [.124] & ${ }^{*}$ Mhyrr Gum [.283] & Turkey Rhubarb [.466] & Sage [.519] \\
\hline *Dichroa Root [.137] & *White Sage [.299] & Cinnamon [.479] & Pipsissewa [.521] \\
\hline Alkanet Root [.138] & ${ }^{*}$ Rosemary [.299] & Cynomorium songaricum [.486] & Vidanga Leaf [.522] \\
\hline Kochia Seed [.147] & *Vitex Powder [.302] & Kava Kava [.491] & Buplerum Root [.524] \\
\hline *Kanta Kari Herb [.157] & Eucalyptus Leaf [.305] & Arjun [.491] & Pipli Fruit [.528] \\
\hline *Sweet Myrrh [.158] & Feverfew [.307] & Babul Chall Bark [.492] & \\
\hline Blue Cohosh Root [.218] & Red Sandlewood [.326] & Black Pepper [.495] & \\
\hline
\end{tabular}

TABLE 1B

ANTI-CANCER SCREEN - CATEGORY 2: MODERATE TO STRONG

\begin{tabular}{llll}
\hline$\rightarrow$ LC $_{50}=$ [0.528-1.197 mg/ml] & & & \\
Horse Chesnut [.528] & Lindera Root [.610] & Damiana Leaf [.691] & Haritaki Fruit Powder [1.013] \\
$\begin{array}{l}\text { Boldo Leaf [.533] } \\
\text { Pomegranate Husk [.535] }\end{array}$ & Sutaj Bark Powder [.612] & Ashoka Leaf [.710] & Schisandra Berry [1.015] \\
Lavender Flower [.539] & Calendula Flower [.621] & Cedar Berries [.752] & Pashanbheda Herb Powder [1.025] \\
Tarragon [.548] & Uva Ursi [.630] & Spikenard [.755] & Garlic Powder [1.074] \\
Green Mosaia [.569] & Bay Leaf [.634] & Karela Fruit [.768] & Neem Leaf [1.074] \\
Black Henna [.576] & Bilberry Leaf [.644] & Barberry Root [.828] & White Willow Bark [1.082] \\
Sambhar Powder [.576] & Licorice Root [.655] & Witch Hazel Root [.847] & Black Cohosh Root [1.163] \\
Usnea [.584] & Lovage Root [.661] & Rabdosia rubescens Herb [.853] & Cranebill Root [1.170] \\
Brahmi Herb [.605] & Rose Petals [.665] & Cramp Bark [.984] & Red Henna [1.197] \\
Nageshkar Leaf Powder [.607] & Pyrite (Fool's Gold) [.679] & & \\
\hline
\end{tabular}

TABLE 1C

ANTI-CANCER SCREEN - CATEGORY 3: MODERATE

$\rightarrow \mathrm{LC}_{50}=[1.259-2.515 \mathrm{mg} / \mathrm{ml}] \rightarrow$

Wintergreen [1.259]

Shatawari Root Powder [1.600] Corriander [2.140]

Catuaba Bark [2.271]

Phytother Res. Author manuscript; available in PMC 2009 March 3. 


\begin{tabular}{llll}
\hline TABLE 1C & & & \\
ANTI-CANCER SCREEN & CATEGORY 3: MODERATE & & \\
\hline Bayberry Root [1.269] & Agrimony [1.641] & Pulsatilla Root [2.153] & Thyme [2.284] \\
Raspberry Leaf [1.349] & Oregano [1.650] & Biota Leaves [2.168] & Strawberry Leaf [2.308] \\
Gravel Root [1.378] & Blessed Thistle [1.739] & Blackberry Root [2.217] & Cat Claw [2.359] \\
Epidedium [1.393] & Ladys' Mantle [1.766] & Linden Leaf [2.230] & Patchouili Leaf [2.361] \\
Butches Broom Root [1.431] & Pennyroyal [1.810] & Catuaba Bark [2.271] & Galangal Root [2.374] \\
Soap Wort [1.449] & Bladderwrack [1.898] & Thyme [2.284] & Birch Bark Root [2.381] \\
Copal Resin [1.457] & Oatstraw [1.903] & Strawberry Leaf [2.308] & Boneset [2.413] \\
Black Walnut Hull [1.468] & Kachnar Bark Powder [1.929] & Cat Claw 2.359] & Bringraj Herb Powder [2.436] \\
Annato Seed [1.507] & Oregon Grape [1.946] & Patchouili Leaf [2.361] & Rhodiola Root [2.476] \\
Habernaro [1.519] & Centipeda Herb [2.026] & Blackberry Root [2.217] & Guarana Seed [2.500] \\
Clove [1.524] & Celery Seed Powder [2.094] & Linden Leaf [2.230] & Saw Palmetto Berry [2.515] \\
Stevia Leaf [1.562] & & & \\
\hline
\end{tabular}

\begin{tabular}{llll}
\hline TABLE 1D & & & \\
ANTI-CANCER SCREEN - CATEGORY 4: WEAK TO MODERATE & & \\
\hline$\rightarrow$ LC $_{50}=[2.528-4.939 \mathrm{mg} / \mathrm{ml}]$ & & & \\
Iceland Moss [2.528] & Lemongrass Tea [3.344] & Sophora Root [3.801] & Celandine [4.346] \\
Meadowsweet [2.543] & Mistle Toe [3.410] & Caraway Seed [3.807] & Black Walnut Leaf [4.508] \\
Savory , Winter [2.563] & Costus Root [3.445] & Garam Marsala [3.873] & Artemisia Leaf [4.533] \\
Allspice Berry Powder [2.582] & Aster Root [3.449] & Paul D'Arko Bark [3.892] & Lychee Pit [4.537] \\
Musta Root Powder [2.632] & Golden Rod [3.548] & Elsholtzia Herb [3.911] & Heather flower [4.598] \\
Olive Leaf [2.720] & Coral Calcium [3.591] & Yerba Mate Leaf [4.017] & Terminalia Fruit [4.614] \\
Bilwa Fruit Powder [2.721] & Maca Powder [3.611] & Yarrow Root [4.038] & Pygeum Bark [4.669] \\
Malva Flower [2.790] & Horehound [3.641] & Siegesbeckia Herb [4.128] & California Poppy [4.790] \\
Maiden Hair Fern [2.882] & Blue Violet Leaf [3.659] & Calamus Root [4.141] & Psyllium Husk [4.821] \\
Wormwood [2.914] & Cumin Seed [3.713] & Drynaria Rhizome [4.189] & Basil [4.871] \\
Buchu Leaf [2.923] & Orris Root [3.737] & Sumar Berries [4.235] & Lemon Balm [4.877] \\
Cascara Sagrada Bark [2.998] & Lemon Verbena [3.747] & Wood Betany [4.302] & Beet Root [4.912] \\
Cayeen Powder [3.192] & Luffa Sponge [3.788] & Curculigo Rhizome [4.341] & Gotu Kola [4.939] \\
Lavan Bhaskar Churna [3.332] & & & \\
\hline
\end{tabular}

\begin{tabular}{llll}
\hline TABLE 1E & & & \\
ANTI-CANCER SCREEN & CATEGORY 5: WEAK & & \\
\hline LC $50>[5.0 \mathrm{mg} / \mathrm{ml}]$ & & & \\
Abalone Shell & Corn Silk & Isatis Leaf & Poke Root \\
Adenophora tetraphylla Root & Cortyceps & Jasmine Flower & Poppy Seed \\
Ailanthus Bark & Couch Grass & Kadsura Stem & Psylliam Seed \\
Albizzia/Mimosa Bark & Cranberry Powder & Kelp & Puff-Ball/Lasiophaera \\
Alfalfa Leaf & Dandelion Root & Knotweed Grass & Purnarnava Herb \\
Alfalfa Seed & Dill Seed & Kola Nut & Pyrrosia Leaf \\
Alum-Processed & Dittany Root-Bark & Kombu & Red Clover \\
Andrographis Herb & Dog Grass Root & Kudzu Root & Reed Rhizome
\end{tabular}




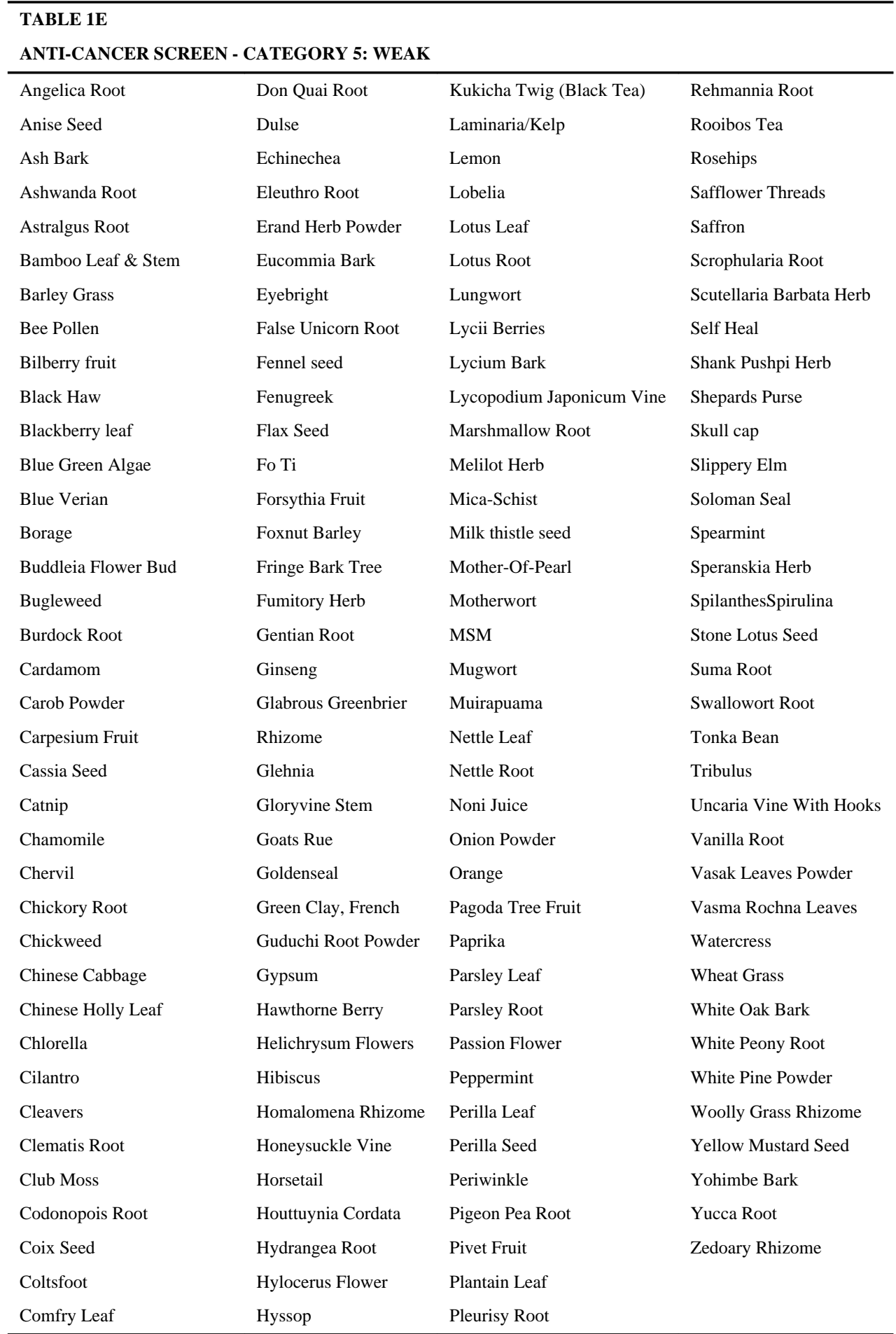

Plants: Common Name; Species, Genus/Abalone Shell; Haliotis diversicolor/Adenophora tetraphylla Rt.; Adenophora tetraphylla/ Agrimony; Agrimonia eupatoria/Ailanthus Bk.; Ailanthis altissima/Albizza; Albizzia julibrissin/Alfalfa Lf.; Medicago sativa/Alfalf a Seed; Medicago satival Alkanet Rt.; Batschia canescens/Allspice Ber Powder; Pimenta dioica/Andrographis Herb; Andrographis paniculatal Angelica Rt.; Angelica archangelica/Anise Seed; Pimpinella anisum/Annato Seed; Bixa orellana/Arjun; Terminalia arjuna/Artemisia Lf.; Artemisia argyi/Ash Bk.; Fraxinus rhynchophylla/Ashoka Lf.; Saraca indica/Ashwanda Rt.; Withania somnifera/Aster Rt.; Aster tataricus/Astragalus Rt.; Astragalus membranaceus/Babul Chall Bk.; Acacia arabica/Bakuchi Seed; Cyamopsis psoralioides/Balm of gilead bud; Populus balsamifera/Bamboo Lf. \& Stem; Lophatherum gracile/BarBer Rt.; Berberis vulgaris/Barley Grass; Hordeum vulgare/Basil; Ocimum basilicum/Bay Lf.; Laurus nobilis/Bay 
Ber Rt.; Morella cerifera/Bee Pollen; from Oregon State bees/Beet Rt.; Beta vulgaris rubra/Bhumy Amalaki; Phyllanthus niruri/Bil Ber fruit; Vaccinium myrtillus/BilBer Lf.; Vaccinium myrtillus/Bilwa Fruit Powder; Aegle marmelos/Biota Lf.; Thuja orientalis; Platycladus orientalis/Birch Bk. Rt.; Betula alba/Birch Lf.; Betula alba/Black Cohosh Rt.; Cimifuga racemosa/Black Haw; Viburnum prunifolium/Black Henna; Indigofera tinctoria/Black Pepper; Piper nigrum/Black Walnut Hull; Juglans nigra/Black Walnut Lf.; Juglans nigra/BlackBer Lf.; Rubus fruticosus/BlackBer Rt.; Rubus fruticosus/Bladderwrack; Fucus vesiculosus/Blessed Thistle; Cnicus benedictus/Blood Rt.; Sanguinaria canadensis/Blue Cohosh Rt.; Caulophyllum thalictroides/ Blue Green Algae; From Klammath Lake/Blue Verian; Verbena hastata/Blue Violet Lf.; Viola odorata/Boldo Lf.; Peumus boldus/ Boneset; Eupatorium perfoliatum/Borage; Borago officinalis/Brahmi Herb; Bacopa monnieri/Bringraj Herb Powder; Eclipta erecta/ Buchu Lf.; Agathosma betulina/Buckthorne Bk.; Rhamnus cathartica/Buddleia Flower Bud; Buddleia officinalis/Bugleweed; Lycopus lucidus/Buplerum Rt.; Bupleurum chinense/Burdock Rt.; Arctium lappa/Bushy Knotweed Rhizome; Polygonum Cuspidatum; Polygonum japonicum/Butchers Broom Rt.; Ruscus aculeatus/Butternut Bk.; Juglans cinerea/Calamus Rt.; Acorus calamus/Calendula Flower; Calendula officinalis/California Poppy; Eschscholzia californica/Caraway Seed; Carum carvi/Cardamom; Elettaria cardamomum/Carob Powder; Jacaranda procera/Carpesium Fruit; Carpesium abrotanoides/Cascara Sagrada Bk.; Rhamnus purshiana/Cassia Seed; Cassia obtusifolia; Cassia tora/Cat Claw; Uncaria tomentosa/Catnip; Nepeta cataria/Catuaba Bk.; Erythroxylaceae catuba/Cayenne Powder; Capsicum minimum/Cedar Berries; Juniperus monosperma/Celandine; Chelidonium majus/Celery Seed Powder; Apium graveolens/Centipeda Herb; Centipeda minima/Chamomile; Matricaria recutita/Chaparral; Larrea tridentata/Chervil; Anthriscus cerefoilium/Chickory Rt.; Cichorium intybus/Chickweed; Stellaria medial Chinese Cabbage; Brassica chinensis/Chinese Holly Lf.; Ilex cornuta/Chlorella; Chlorella pyrendoidosa/Cilantro; Coriandrum Sativum/Cinnamon; Cinnamomum cassia Cleavers; Galium aparine/Clematis Rt.; Clematis chinensis/Clove; Syzygium aromaticum/Club Moss; Lycopodium clavatum)/ Codonopois Rt.; Codonopsis pilosula/Coix Seed; Coix lachrymal/Coltsfoot; Tussilago farfara/Comfry Lf.; Symphytum officinale/Copal Resin; Bursera/Coral Calcium; Barefoot/Corn Silk; Zea mays/Coriander; Coriandrum sativum)/Cordyceps; Cordyceps sinensis/Costus Rt.; Saussureae lappa; Saussurea costus/Couch Grass; Agropyrum repens/Cramp Bk.; Viburnum opulus/CranBer Powder; Vaccinium macrocarpon/Cranebill Rt.; Geranium maculatum/Cubeb Ber; Piper cubeba/Cumin Seed; Cuminum cyminum L./Curculigo Rhizome; Curculigo orchioides/Cynomorium herb; Cynomorium songaricum/Damiana Lf.; Turnera diffusa/Dandelion Rt.; Taraxacum officinale)/Dichroa Rt.; Dichroa febrifuga/Dill Seed; Anethum graveolens/Dittany Rt.-Bk.; Dictamnus dasycarpus/Dog Grass Rt.; Triticum repens/Don Quai Rt.; Angelica sinensis/Dragons Blood; Daemomorops draco/Drynaria Rhizome; Drynaria fortunei/Dryopteris Male Fern Rhizome; Dryopteris crassirhizoma/Dulse; Rhodymenia palmetto/Echinechea; Echinacea Purpurea/Elecampane Rt.; Inula helenium/Eleuthro Rt.; Eleutherococcus senticosus/Elsholtzia Herb; Elsholtzia splendens/Epidedium; Epimedium grandiflorum/Erand Herb Powder; Castor; Ricinus communis/Eucalyptus Lf.; Eucalyptus globules/Eucommia Bk.; Eucommia ulmoides/Eyebright; Euphrasia officinalis/False Unicorn Rt.; Chamaelirium luteum/Fennel seed; Foeniculum vulgare/Fenugreek; Trigonella foenum-graecum/Feverfew; Tanacetum parthenium/Flax Seed; Linum usitatissimum/Fo Ti; Polygonum multiflorum/Forsythia Fruit; Forsythia suspense/Foxnut Barley; Euryale ferox/Frankincense; Boswellia carteri/Fringe Bk. Tree; Chionanthus virginicus/Fumitory Herb; Fumaria officinalis)/Galangal Rt.; Alpina officinalis/Garcinia Fruit; Garcinia cambogia/ Garlic Powder; Allium sativum/Gentian Rt.; Gentiana lutea/Ginger Rt.; Zingiber officinale/Ginseng; Panax quinquefolium/Glabrous Greenbrier Rhizome; Smilax glabra/Glehnia; Glehnia littoralis/ Gloryvine Stem; Sargentodoxa cuneata/Goats Rue; Galega officinalis/Golden Rod; Solidago virgaurea/G oldenseal; Hydrastis Canadensis/Gotu Kola; Centella asiatica/Gravel Rt.; Eupatorium purpureum/ Green Clay, French; mineral oxides, magnesium, calcium, potassium, dolomite, silica, manganese, phosphorus, silicon, copper and selenium/Green Tea; Camellia sinensis/Guarana Seed; Paullinia cupana/Guduchi Rt. Powder; Tinosporia cordifolia/Gymnema; Gymnema sylvestre/Gypsum; Gypsum fibrosum/Habernaro; Capsicum chinense/Haritaki Fruit Powder; Terminalia chebula/Hawthorne Ber; Crataegus laevigata/Heather flower; Calluna vulgaris/Helichrysum Flowers; Helichrysum italicum/Hibiscus; Hibiscus sabdariffa/Homalomena Rhizome; Homalomena occulta/Honeysuckle Vine; Lonicera japonica/Horehound; Marrubium vulgare/Horse chestnut; Aesculus hippocastanum/Horsetail; Equisetum arvense/Houttuynia Cordata; Houttuynia cordata/Hydrangea Rt.; Hydrangea arborescens/ Hylocerus Flower; Hylocereus undatus/Hyssop; Hyssopus officinalis/Iceland Moss; Cetraria islandica/Isatis Lf.; Isatis indigotica; Isatis tinctoria/ Jasmine Flower; Jasminum officinale/Kachnar Bk. Powder; Bauhinia tomentosa/Kadsura Stem; Piper futokadsura/Kanta Kari Herb; Solanum xanthocarpum/Karela Fruit; Momordica charantia/Kava Kava; Piper methysticum/Kelp; Laminaria digitata, japonica/ Knotweed Grass; Polygonum aviculare/Kochia Seed; Kochia scoparia/Kola Nut; Cola acuminate/Kombu; Laminaria setchellii/Kudzu Rt.; Pueraria lobata/Kukicha Twig; Camellia sinensis L./Kutaj Bk. Powder; Holarrhena Antidysenterica/Ladys' Mantle; Alchemilla vulgaris/Laminaria/Lavan Bhaskar Churna; Mixture of Coriandrum sativum, Piper longum Rt., Cinnamomum tamale, Garcinia pedunculata, Cuminum cyminum, Zingiber officinale, Cinnamomum zeylanicum, Elettaria cardamomum, Piper nigrum/Lavender Flower; Lavandula officinalis/Lemon; Citrus limon/Lemon Balm; Melissa officinalis)/Lemon Verbena; Aloysia triphylla/Lemongrass Tea; Cymbopogon citrates/Licorice Rt.; Glycyrrhiza glabra/Linden Lf.; Tilia europaea/Lindera Rt.; Lindera strychnifolia/Lobelia; Lobelia inflate/Lotus Lf.; Nelumbo nucifera/Lotus Rt.; Nelumbo nucifera/Lovage Rt.; Levisticum officinale/Luffa Sponge; Luffa cylindrical/ Lungwort; Pulmonaria officinalis/Lychee Pit; Litchi chinensis seed/Lycii Berries; Lycium chinense/Lycium Bk.; Lycium chinense/ Lycopodium Japonicum Vine; Lycopodium japonicum/Maca Powder; Lepidium meyenii/Mace; Myristica fragans/Maiden Hair Fern; Adiantum capillus/Malva Flower; Malva spp/Marshmallow Rt.; Althaea officinalis/Meadowsweet; Filipendula ulmarial Melilot Herb; Melilotus officinalis/Myrrh Gum; Commiphora molmol/Mica-Schist; Vermiculite schist mineral/Milk thistle seed; Silybum marianum/ Mistletoe; Phoradendron flavescens/Mother-Of-Pearl; Margaritifera concha shell; Motherwort; Leonurus cardiaca/Mugwort; Artemisia vulgaris/Muirapuama; Ptychopetalum olacoides/Musta Rt. Powder; Cyperus rotundus/Nageshkar Lf. Powder; Mesua ferrea/Neem Lf.; Azadirachta indica/Nettle Lf.; Urtica dioica/Nettle Rt.; Urtica dioica/Noni Juice; Morinda citrifolia/Nutmeg; Myristica fragans/Oatstraw; Avena sativa/Olive Lf.; Olea europaea/Onion Powder; Allium cepa/Orange; Citrus sinensis/Oregano; Origanum vulgare/Oregon Grape; Mahonia aquifolium/Orris Rt.; Iris germanica/Osho Rt.; Ligusticum porteri/Pagoda Tree Fruit; Melia Toosendan/Papaya Lf.; Carica papaya/Paprika; Capsicum annuum/Parsley Lf.; Petroselinum crispum/Parsley Rt.; Petroselinum crispum/Pashanbheda Herb Powder; Coleus aromaticus/Passion Flower; Passiflora incarnate/Patchouili Lf.; Pogostemon cablin/Paul D'Arko Bk.; Tabebuia impetiginosa/Pennyroyal; Mentha pulegium/ Peppermint; Mentha piperita/Perilla Lf.; Perilla frutescens/Perilla Seed; Perilla frutescens/ Periwinkle; Vinca minor/Pigeon Pea Rt.; Sophora subprostrata/Pipli Fruit; Piper longum/Pipsissewa; Chimaphila umbellate/Pivet Fruit; Ligustrum lucidum/Plantain Lf.; Plantago major/Pleurisy Rt.; Asclepias tuberose/Poke Rt.; Phytolacca Americana/Pomegranate Husk; Punica granatum rind/Poppy Seed; Papaver somniferum/Psoralea Fruit; Psoralea corylifolia/Psyllium Seed; Plantago psyllium/Psyllium Husk; Plantago psyllium/Puff-Ball; Lasiosphaera fenslii/Pulsatilla Rt.; Pulsatilla chinensis/Purnarnava Herb; Boerhaavia diffusa/Pygeum Bk.; Pygeum africanum/Pyrite (Fool's Gold); Iron Sulfide/Pyrrosia Lf.; Pyrrosia 
Lingua/Dong Ling Cao; Rabdosia rubescens/RaspBer Lf.; Rubus idaeus/Red Clover; Trifolium pretense/Red Henna; Lawsonia inermis/Red Sandalwood; Pterocarpus santalinus/Red Rt.; Ceanothus americanus/Reed Rhizome; Phragmitis communis/Rehmannia Rt.; Rehmannia glutinosal Rhodiola Rt.; Rhodiola rosea/Rooibos Tea; Aspalathus linearis/Rose Petals; Rosa spp./Rosehips; Rosa canina/Rosemary; Rosmarinus officinalis/ Safflower Threads; Carthamus tinctorius/Saffron; Crocus sativus/Sage; Salvia officinalis Sambhar Powder; mixture of Coriander, Coriandrum sativum L.; chilli, Fenugreek; Trigonella foenum-graecum Cinnamon; Cinnamomum cassia, Cumin Seed; Cuminum cyminum L., Cayenne Powder; Capsicum minimum, Black Pepper; Piper nigrum, asafoetida; Ferula asafoetida; Sasparilla; Smilax medica/Savory, Winter; Satureja Montana/Saw Palmetto Ber; Serenoa repens/Schisandra Ber; Schisandra chinensis/Scrophularia Rt.; Scrophularia ningpoensis/ Scutellaria Barbata Herb; Scutellaria barbata/Self Heal; Prunella vulgaris/Senna Lf.; Senna alexandrina/Shank Pushpi Herb; Convolvulus pluricaulis/Shatawari Rt. Powder; Asparagus racemosus/Shepherds Purse; Capsella bursa-pastoris/Siegesbeckia Herb; Siegesbeckia orientalis/Skull cap; Scutellaria laterifloral Slippery Elm; Ulmus rubra/Soap Wort; Saponaria officinalis/Soloman Seal; Polygonatum biflorum/Sophora Rt.; Sophora flavescens/Spearmint; Mentha spicata/Speranskia Herb; Speranskia tuberculata/Spikenard; Aralia racemosa/Spilanthes; Spilanthes acmella/Spirulina; Arthrospira platensis/Stevia Lf.; Stevia rebaudiana/Stone Lotus Seed; Sinocrassula indica/StrawBer Lf.; Fragaria vesca/Suma Rt.; Pfaffia paniculata/Sumar Berries; Pfaffia paniculata/Superior Gun Powder; Camellia sinensis L./Swallowort Rt.; Cynanchum atratum/Sweet Myrrh; Opopanax/Tarragon; Artemisia dracunculus/Teasel Rt.; Dipsacus asper/ Terminalia Fruit; Terminalia chebula/Thyme; Thymus vulgaris/Tonka Bean; Dipteryx odorata/ Tribulus; Tribulus terrestris/Turkey Rhu-barb; Rheum palmatum/Uncaria Vine With Hooks; Uncaria rhynchophylla/Usnea; Usnea spp/Uva Ursi; Arctostaphylos uva ursi/Vanilla Rt.; Vanilla planifolia/Vasak Lf. Powder; Adhatoda vasica/Vasma Rochna Lf.;Bambusa arundinacea/Vidanga Lf.; Embelia ribes/Vitex Powder; Vitex agnus-castus/Watercress; Nasturtium officinale/Wheat Grass; Triticum aestivum/White Oak Bk.; Quercus alba/ White Peony Rt.; Paeonia Lactiflora/White Pepper Corns; Piper nigrum/White Pine Powder; Pinus strobes/White Sage; Salvia apiana/White Willow Bk.; Salix alba/Wild Cherry Bk.; Prunus serotina/Wild Yam; Dioscorea villosa/Wintergreen; Gaultheria procumbens/Witch Hazel Rt.; Hamamelis virginiana/Wood Betany; Betonica officinalis/Woolly Grass Rhizome; Imperata cylindrical/Wormwood; Artemisia absinthum/Yarrow Rt.; Achillea millefolium/Yellow Dock Rt.; Rumex crispus/Yellow Mustard Seed; Sinapis Alba/Yerba Mate Lf.; Ilex paraguarensis/Yohimbe Bk.; Corynanthe yohimbe/Yucca Rt.; Yucca filamentosa/Zedoary Rhizome; Curcuma zedoaria. Non-plantae Kingdom Extracts: Kingdom: Monera Blue Green Algae; Aphanizomenon-Flos-Aquae, Kingdom: Animalia, Abalone Shell; Haliotis, Kingdom: Chromalveolata, Bladderwrack, Kingdom Protista; Kelp; Laminaria digitata, Kombu; Laminaria setchelli, Kelp Laminaria japonica, Kingdom Fungi - Usnea; Usnea spp, Iceland Moss; Cetraria islandica Chlorella; Chlorella pyrendoidosa, Cordyceps; Cordyceps sinensis. Additional extracts included extract of processed alum (Aluminum Potassium Sulfate), French Green Clay (mineral oxides, magnesium, calcium, potassium, dolomite, silica, manganese, phosphorus, silicon, copper and selenium.), coral calcium, methylsulfonylmethane (MSM), and garam masala (Cardamon, organic Cinnamon, organic Clove, organic Cumin, organic Black Pepper and Coriander).

* Denotes herbs that are generally known to be safe for human consumption at low to moderate use. 